\title{
Destination Management in Lesvos, Greece. Characteristics, Preferences, Images, Satisfaction and Overall Experience
}

\author{
http://doi.org/10.21272/bel.4(3).81-106.2020
}

Mary Constantoglou, ORCID: https://orcid.org/0000-0002-4365-3349

Adjunct Lecturer, Department of Economics and Tourism Management, University of Aegean, Chios, Greece

\begin{abstract}
As the tourism sector is continually evolving, touristic destinations and service providers should give close and thoughtful attention to customers' satisfaction, particularly during the Covid-19 pandemic period. Tourism for Greece represents one of the most valuable pillars of the economy and the impact of the pandemic to the sector and GDP will be significant. In this era, it is evident the importance of the Sustainable Development Goals and effective Destination Management that will take into consideration all aspects of the local communities. Customer satisfaction is crucial to improving strategies that destinations must follow to service quality and satisfaction management strategies. Recent consumer and technological trends make customer satisfaction more important than ever. This paper aims to investigate the characteristics, preferences, images, satisfaction levels, and the overall experience gained by the tourists visiting Lesvos island in the North Aegean Region Greece. Primary research was conducted and the airport of the island during departure in 2019. The useful gathered questionnaires (201) provided helpful information to the island's DMO related to the visitors' demographic characteristics, destination perception, awareness and competitiveness, satisfaction and overall experience. The basic research findings were the strong impression of the visitors about the authenticity of the destination. They also believe that prices are excellent and the rate of value for money is high. At the same time, visitors think that the island is not promoted very good and the image/brand of the island is not very clear and well defined. It is the first research conducted to visitors departing from Lesvos island to the authors' best knowledge. The results and discussion of this study will be useful to the islands' DMO and the island's tourism authorities and the North Aegean Region and other similar island destinations, which wish to maximize the benefits of tourism development.
\end{abstract}

Keywords: Destination Management Organization, Destination Image, Branding, Visitor Satisfaction, Experience.

JEL Classification: L83, Z32, Z33, Z38.

This work is licensed under a Creative Commons Attribution 4.0 International License

Cite as: Constantoglou, M. (2020). Destination Management in Lesvos, Greece. Characteristics, Preferences, Images, Satisfaction and Overall Experience. Business Ethics and Leadership, 4(3), 81-106. http://doi.org/10.21272/bel.4(3).81-106.2020.

(C) The Author, 2020. This article is published with open access at Sumy State University.

\section{Introduction}

Since the tourism sector is continually evolving, touristic destinations and service providers should give close and thoughtful attention to customers' satisfaction, particularly during the Covid-19 pandemic period. With no vaccine to prevent the expansion of the disease, most countries turned to other "non-pharmaceutical interventions" (Gössling, Scott and Hall, 2020). Examples are locked down, social distancing, closure of schools and universities, changing workplaces postponing events and many others (Gössling, Scott and Hall, 2020). The restrictions mentioned above have changed the world in every respect and, consequently, the tourism system, including the international and domestic travel, tourism demand, and the general tourism industry (Wu and Chang, 2020; Gössling, Scott and Hall, 2020). The spread of COVID-19 results to essential changes to the way that tourists are traveling, having safety and security as the most significant parameters in their journey since they can change quickly and without warning WTTC, 2020). After all, there is evidence justifying that "COVID-19 will be different and transformative for the tourism sector" (Gössling, Scott and Hall, 2020). However, many people continue to travel either for leisure, business, and humanitarian purposes (WTO, 2020). Monitoring customer satisfaction is very crucial to improve the strategies on service quality and satisfaction management. The recent consumer and technological trends make customer satisfaction more important than ever before (Confente, 2015; 
Möhlmann, 2015; Sharma and Baoku, 2013; Sparks and Browning, 2010; Wang, 2016). These trends justify that consumers are continuously searching for new ways of 'purchasing' and 'consuming' tourism.

\section{Literature Review}

Oliver (1997) and Wang (2016) define satisfaction as the consumers' overall cognitive or affective response to product use. Besides, (Chen, Huang and Petrick 2016; Wang, 2016) argue that satisfaction is customers' judgment of whether a product or service provides a level of consumption-related fulfillment. In the article (Uncles, East and Lomax, 2013), customer satisfaction is determined by "overall feelings, or attitudes, a person has about a product after it has been purchased". Various researchers examined tourist satisfaction and loyalty since they are the key determinants of tourism success (Eusebio and Vieria, 2013; Herle, 2018; Wang, 2016). Satisfied tourists usually transmit their experiences to others and revisit the place (Wang, 2016; Herle, 2018; Chen, Cheng, and Kim, 2020; Abdellatif, Ksouri, Ayoun, and Storai, 2014). As literature affirms, tourists' satisfaction results from the combination of various variables (Herle, 2018; Abdellatif, Ksouri, Ayoun, and Storai, 2014), which are determined by the comparison of tourists' perception of products and services they receive and their expectations before and during the trip (Wang, 2016). Yet, some researchers and practitioners support a new strategy for creating customer loyalty based on consumers' experiences and emotions. (Chen, Cheng, and Kim, 2020; Stylos, Bellou, Andronikidis and Vassiliadis, 2017). Besides, in the tourism context, satisfaction is primarily referred to as a function of pre-travel expectations and post-travel experiences. The tourist is satisfied when experiences go beyond the expectations (Aliman, Hashim, Wahid and Harudin, 2016). However, if the tourist feels displeasure, dissatisfaction will be expected (Chen and Chen, 2010; Wang, 2016). Considering the above, tourists' satisfaction is one of the essential variables when analyzing tourist behavior, as it influences the destination selection, the consumption of products and services, and the decision to return.

2.1 Assessing the level of satisfaction. Many theories and perspectives in the sector of tourism have worked with the analysis of tourists' satisfaction and one of them is a paradigm proposed by Oliver (1980) and Oliver and Desarbo (1988). The Expectancy Disconfirmation Theory discusses that tourists have previous expectations before even receive the service and it is compared with the perceived outcome of the offered service. Also, the Equity Theory supports that tourist satisfaction can be considered as a relationship among the sacrifices and rewards the tourist expects in terms of time, cost or effort and value received (Oliver and Swan, 1989). The Normative Theory specifies the need to set a common point as a reference to which individuals' opinions can be measured about Latour and Peat (1979) work. Therefore, tourists could compare their present destinations with other alternatives or previous experiences (Yoon and Uysal, 2005). Many countries have created tools to measure satisfaction like the Swedish Customer Satisfaction Barometer (SCSB), the American Customer Satisfaction Index (ACSI), the Norwegian Customer Satisfaction Barometer and the European Customer Satisfaction Index, which was introduced in 2000 (Tovmasyan, 2019).

2.2 Satisfaction Variables. Assessing the level of tourist satisfaction is not sufficient if it is measured in isolation of other variables. In a study related to customers' emotional outcomes of a tourist experience, which are often associated with the emotions of pleasure and indulgence, Ma, Gao, Scott and Ding (2013) believe that a psychological perspective must be embedded. Bigne and Andreu (2004) support that satisfaction is a cognitive and emotional phenomenon and they proposed a cognitive/emotional integrating model to explain satisfaction. Oliver proposes in (Oliver, 2015) an interesting definition that satisfaction is a "pleasurable fulfillment". Besides, the study (Giese and Cote, 2000) supports that satisfaction levels are associated with the context in which it is evaluated. They argue that there are three essential elements of context: a) response to an emotional judgment, b) a specific aspect of the service and c) a particular moment in time. In sum, it is essential to consider that the costumers' reaction to emotional experiences depends on the situational context and the complexity of the subject's interpretation or valuation of the subject's activities. Few studies exist that focus on analyzing the causes that lead to a certain level of satisfaction. It is necessary to perceive satisfaction as a process linked to the offered service needs, motivations, and characteristics to understand the emotional experiences that clients may face during their interaction with the service providers (Gountas and Gountas, 2007).

Several researchers are trying to analyze why people are traveling and what they are expecting from their destination. They are mainly interested in the motives behind their trip (Vuuren and Slabbert, 2011; Andrades, Dimanche, and Likevich, 2015). Jang and Feng (2007) support that motivation is a dynamic process of inner psychological factors and words such as choice, effort, novelty and persistence involve overtime. First, it is very important to understand each tourist and the forces that drive individuals to be tourists. These forces are categorized in intrinsic and extrinsic approaches to motivation regarding the (Page, 2011). In particular, the intrinsic approach pinpoints that every person has unique needs that simulate them to consume tourism, some of which are associated with fulfilling their individual or internal requirements. On the other hand, the extrinsic 
approach to motivation examines external factors such as attitudes, preferences and perceptions. Although analyzing tourist motivation is based on psychological values and features (Page, 2011), it is argued that tourism demand is derived from a consumer decision-making process at a practical level. Three elements are generated through this process; a)energizers of demand: factors that influence individuals on their decision of selecting a holiday, b)filterers of demand: psychological, sociological and economic constraints besides individuals' desire to travel and to go on holiday, c) affecters: factors that either enhance or diminish the energizers of demand, meaning those factors which influence the selection of a holiday. Although the above factors influence the travel decision-making process, they still do not explain the reasons that motivate people to travel or to go on holiday. Page (2011) suggests the usefulness of understanding how the needs and desires of individuals fit in their lives. Finally, it argues that Maslow's hierarchy model can be understood in a tourism context.

Furthermore, tourist literature defines motivation as a series of needs that force individuals to participate in a tourist activity (Pizam, Neuman and Reichel, 1978). Besides, Sadeh et al. (2012) consider expectations an essential variable of satisfaction in the service sector. The levels of expectations and satisfaction are of great importance in sustainable tourism development at a given destination. Many definitions have been given to describe expectations, some of which can be found in Akama and Kieti (2003) studies and, most recently, in the Dixit, (2017) that suggest that tourists have an initial expectation of service before they consume it. Bosque, Martín, and Collado, (2006) indicate that expectations are formed through experience, which can be described as the tourist's level of previous satisfaction with the service, communication from the service provider and the tourist's perceived image of the service. Finally, it is believed that expectations are always changing as tourists are well informed about the alternative options in the tourism industry. Tourists' expectations can influence their feelings about a service or product and consequently, their satisfaction. Tourist expectation affects the perceived value and satisfaction (Song et al., 2012; Lee et al., 2011). The destination expectation can be the basis for assessing the money paid and the service delivered.

Another essential variable of satisfaction is the perceived quality of service, which is determined by customer perception. Tourism research defines perceived quality as the "visitor's assessment of the standard of the service delivery process in association with the trip experience" Other researchers suggest that the essential requirement that increases tourists' satisfaction is the quality of service offered (Chen and Tsai, 2007; González, Comesaña and Brea, 2007; White, 2006). Among many researchers, the tourist perceived values about tourists' satisfaction since the customer's assessment of the services based on the perceptions of what is received and what is given. Lovelock (2000) suggests that the perceived value is a trade-off between perceived benefits and perceived costs. As equity theory also reveals (Oliver and Swan, 1989), satisfaction exists when the amount received is more than what is spent by the customer. Besides, the researchers Song et al. (2012), Chen and Chen (2010), Haung and Su (2010) support that tourists will feel satisfied if the quality of service provided is higher than the money paid. Every tourist will consider the costs and risks encountered when planning to travel to a destination. Expenses and Risks can be increased or low and that is depending on individuals' personalities. The low risk and the low cost can influence repeated visitations and destination reputation for safety (Aliman, Hashim, Wahid and Harudin, 2016). Many factors can influence perceived costs and risks, some of them are the experience, personal characteristics, ecosystem forces such as political stability, economic conditions and so on. Therefore, many travelers choose to travel to destinations that offer low costs and low risks. Another key variable of satisfaction related to the holiday decision process is the distance to the destination. Studies that are dealing with destination selection discuss that the distance of a destination may either be a deterring or an attractive factor (Nicolau and Más, 2006). The selection of a distant destination depends on tourists' desires and time availability. In the work of Aliman, Hashim, Wahid, and Harudin (2016), it is discussed that the image of a destination is also significant since it influences tourists' behavior, such as their decision-making process, selection of destination and, of course, satisfaction. According to Chen and Kerstetter (1999), tourists' selection of a destination over another, highly depends on the positive image aspects instead of the negative ones. Some other researchers support that destination image must be positive and strong enough to be selected by travelers (Ross, 1993; Hunt, 1975). Finally, cultural characteristics can also influence satisfaction. Wan and Chu (2013) suggest that unsatisfied customers in an individualistic culture are more likely to complain about service failure than those in a collectivist culture.

2.3 Destination Variables. Although satisfaction is the focus of businesses operation, it is also the most powerful indicator of destination performance and management as it shows the way to differentiation. Choosing a destination is a decision process which includes various factors such as the expectations before and after the trip and the tourists' perception of the service (Mcdowall, 2010). Many research articles argue that tourists evaluate a place regarding their feelings or the effective quality of the destination. Visitors may 
also be motivated by place's appearance, sights and/or emotional qualities that will eventually help to fulfill their psychological needs (Kim, Ritchie, and Mccormick, 2010; Marinao, 2018; Franzoni and Bonera, 2019; Chen, Cheng, and Kim, 2020; Marinao, 2018; Franzoni and Bonera, 2019). A destination creates links with the visitors which can be positive, neutral or negative. Therefore, it can create strong relations between products and emotions in tourists' mind (Marinao, 2018).

According to (McGehee, Loker-Murphy and Uysal, 1996), tourists need to travel and look for products that initially feel that they can satisfy their needs. In the decision process, they are influenced by internal and emotional factors and the characteristics and the activities provided by the destination (Uysal and Jurowski, 1994). The dynamic model of tourist behavior discussed in Woodside and Dubelaar (2002) reveals that tourists' decisions and behavior depend on the relationships between different variables generated in three stages. The first stage relates to those variables that lead to the decision before the journey and influence tourists' behavior at the destination. The second stage relates to the tourists' experience at the destination. It includes those variables that are associated with the consumption of the service. The third stage looks at the variables related to tourists' experience and their intended behavior. In the light of the above, tourism destination is a "complex activity of goods, services and production units which offers a tourism experience to individuals or groups of people who temporarily leave their place of permanent residence and travel to a tourism destination of their choice, to satisfy their tourism needs or desires" (Gaki, Kostopoulou, Parisi, and Lagos, 2016). It is further supported that tourists have become more mature and informed, and selecting a tourist destination becomes even more complicated.

Every tourist destination offers multiple services from which tourists have the opportunity to select from a wide range of available alternatives according to their age, income, cost, risk, distance and so on (Kozak, 2002; Beigpoor Shahrivar, 2012). Other researchers have tried to classify the main attributes of every destination. For example, the variable of destination image has strengthened factors like climate, culture, architecture, transport, entertainment and cost (Rodriguez et al., 2006; Beigpoor Shahrivar, 2012). The information about a destination that visitors retrieve from the various sources, results in the formation of a Destination Image in their minds (Molinillo, Liébana-Cabanillas, Anaya-Sánchez, and Buhalis, 2018) Destination image is particular important in tourism destination success because it can influence the destination selection (Molinillo, Liébana-Cabanillas, Anaya-Sánchez and Buhalis, 2018). Interesting are also the definition given by (Crompton, 1979) "the sum of beliefs, ideas, and impressions that a person has of a destination". More recently, (Lai and $\mathrm{Li}, 2016: 10$ ) have defined tourist destination image as "a voluntary, multisensory, primarily picture like, qualia-arousing, conscious, and quasi-perceptual mental (i.e., private, non-spatial, and intentional) experience held by tourists about a destination". Dann (1977) also refers that individual motivations are classified in Push and Pull factors. The 'Push' factors are intangible aspects, for instance, the individual inner desires which are linked to internal and emotional factors (Kassean and Gassita, 2013). Such motivations are the desire for rest, adventure, relaxation, health, social and family relationships and drive tourists to live new experiences (Yoon and Uysal, 2005). On the other hand, the 'Pull' factors are the tangible aspects of a trip like the image or the degree of attractiveness the destination has (Kassean and Gassita, 2013). Since motivation is a dynamic concept and can change in time, different tourist profiles-which are also dynamic-, depend on this variable (Jang and Feng, 2007). Therefore, motivation has been characterized as a segmentation variable in tourism that helps tourist industry to promote those attributes that best suits certain group of tourists (Laws, 1991; Kim, 1999; Kozak, 2002). As Wesley et al. (2006) supports the variation in tourists' profiles, lead to different styles of costumer or consumer purchasing decision.

Additionally, previous studies of (Chu and Choi, 2000; Crotts and Erdmann, 2000; Füller and Matzler, 2008; Reisinger and Turner, 1997, 1998; Turner, Reisinger and McQuilken, 2002; Yu and Goulden, 2006 ) argue that satisfaction may vary according to socio-demographic and trip characteristics such as age, occupation, lifestyle, country of origin, national culture and purpose of trip. Other study included socio-economic and behavioral indicators as inevitable factors that influence tourist satisfaction, thus, other variables that added to the previous list are marital status, education, income and ethnic background (Beigpoor Shahrivar, 2012). A definition for tourist satisfaction has been discussed for many years, and many approaches are associated with it. In this research Tourist satisfaction could be defined as "a collection of tourists' attitudes about specific domains in the vacationing experience" (Pizam, Neumann, and Relchel, 1978: 317). To this extent tourist satisfaction is the experience they gained from their visit in a specific destination. Tourism is seen as a business of selling memorable experiences. Therefore, tourists are planning a trip to visit a desirable destination according to their needs, they are consuming the products or experiences the place is offering, they are creating memories and they are sharing these memories. During their trip they have contacted with service providers or host residents. Throughout the entire process tourists create their own opinions of a destination by comparing 
their actual experiences with their expectations. Customers formed expectations based on their experience, friends and relatives, marketers and competitor's information, and promises (Mcdowall, 2010). If performance exceeds expectations, they are satisfied otherwise, if they do not meet their expectations, are dissatisfied. Additionally, it is observed that the contemporary tourist wants to live a unique experience and is not particularly interested in purchasing a standardized product/service. The tourist destinations must give priority in achieving tourist satisfaction to meet the new needs (Corte, 2015). Tourist satisfaction assists in understanding the performance of destinations. If destinations identify attributes that satisfy the visitors, increase the chances of convincing tourists to revisit. Mcdowall (2010) perceive satisfaction as part of a "vacation sequence", which is also constructed along with generic expenditure, information acquisition, joint decision-making, vacation activities, and subsequent satisfaction and complaints.

Tourism is considered one of the most competitive industries since the managers (DMOs) must understand tourists' needs and develop quality products and services to satisfy their needs. There is an excessive need to measure tourist satisfaction and offer more authentic experiences to tourists to increase destination loyalty and competitiveness among tourist destinations. One of the best ways to evaluate tourist satisfaction is through surveys. Surveys in tourism are a monitoring tool that identifies the level of satisfaction and contributes to improving destinations' quality and competitiveness. Undoubtedly, a tourist satisfaction survey aims to determine the level of fulfillment of tourist expectations and the key components that attract tourists to a destination. The survey ultimate goal is to collect data and construct a baseline for evaluating visitor satisfaction, considering various variables related to tourist's satisfaction and destination when they formed. Besides identifying tourists' needs, measuring the level of satisfaction, and pinpointing the authentic experiences may have during their visit, a survey may also generate suggestions on priorities for products and service and understand tourists' motives and selection of activities. Surveys may collect information about all aspects of the trip; from planning, information sources, reasons for choosing the destination, infrastructure, transportation, gastronomy, cultural heritage, etc. Moreover, it measures which of these components and to what degree they influenced positively or negatively the overall tourist satisfaction of a given destination (Ahmetaj, 2019).

2.4 Destination Management Organisations. According to WTO (2007), destination management calls for a coalition of many organizations and interests working towards a common goal. The DMO's role should be to lead and coordinate activities under a coherent strategy. The tourism industry defines Destination management as a process that involves coordinated actions in managing marketing, local accommodation, tours, events, activities, attractions and transportation and other sources as activities that target to control the economic, socio-cultural and environmental aspects of a destination. Destination management aims at assuring that tourism positively affects the destination in terms of maximizing the benefits of supply and demand. DMO is a management process that not only ensures tourism is beneficial for a destination, but it also helps to develop its long term travel and tourism strategy. The responsibilities of DMOs may be different according to tourism destinations (Tuohino and Konu, 2014). They also argue that in some areas, the DMO may play a crucial role in destination development and growth, which is defined in terms of the "number of visitor arrivals and their expenditure"(Hall and Veer, 2016), others - a minor role.

DMOs are a remarkable component of the tourism system. In (Molinillo, Liébana-Cabanillas, Anaya-Sánchez, and Buhalis, 2017), DMOs are described as a "strategic leader in destination development" responsible for driving and coordinating all the components that constitute a destination such as marketing, attractions, amenities, access and pricing. In tourism, industry perceptions are essential for destination competitiveness (Hall, 2014). DMOs are considered, by industry and other stakeholders, as a tool useful for attracting tourists, public funds for tourism promotional and other campaigns that would otherwise not be obtained. Under the above circumstances, DMOs will likely continue its necessity and continuation (Hall and Veer, 2016). Yet, it is essential to realize that DMO should consider a range of social, political and economic changes that affect the control and the power relations for managing tourism' (Dredge, 2016; Hall, 2010; Hall, 2011).

The Internet and WEB 2.0 have changed the way that users and travelers access information and share their travel experiences and the method of planning and booking their trips. Many tourists use social media to decide destinations, accommodations, restaurants, tours and attractions (Chung and Buhalis, 2008). The most significant evolution in the era of the Internet is the development of social media. More specifically, the various social media platforms allow users to communicate, collaborate, and share their content examples of videos, wikis, blogs, photos, and others. Besides, there are many websites and review sites used by online travelers that host consumer-generated context and online advertisements (Hays, Page, and Buhalis, 2013). As such, WEB 2.0 supports the integration of "information presentation, collaboration, communication, interactivity 
and transaction" (Gretzel, Fesenmaier, Formica, and O'Leary, 2006: 147). An interesting subject in tourism research since the $90 \mathrm{~s}$ is the use of information and communication technologies (ICTs) by DMOs (Molinillo, Liébana-Cabanillas, Anaya-Sánchez, and Buhalis, 2018; Buhalis, 1993, 1998; Poon, 1993; Sheldon,1997). The evolution of the Internet has changed the marketing practices of DMOs (Law, Buhalis, and Cobanoglu, 2014), which have to face the challenges that have been arisen and change their strategies to meet the current requirements (Hays, Page, and Buhalis, 2013). DMOs can use the Internet to customize their information and directly interact with tourists (Hays, Page, and Buhalis, 2013; Law et al., 2014; Buhalis and Law, 2008; Pike and Page, 2014), that lately are extensively using as source of information the existing DMOs' websites and social media (Qi, and Buhalis, 2010; Woodside, Ramos-Mir, and Duque, 2011). Online information influence tourists' behavior. Tourists' interaction with websites and social media allows individuals to travel to the desired destinations without physically being there (Buhalis and Law, 2008), which leads to the formation of the destination image.

It is argued that due to the rapid development of social media, marketers and institutions cannot have total control over the destination image or a product. (Hays, Page, and Buhalis, 2013). Since 2006, Gretzel, Fesenmaier, Formica, and O'Leary have discussed the challenges that DMOs may face due to the internet and social media evolution. They suggest that DMOs have had websites and online advertising before the evolution of WEB 2.0 and social media. Changes in media technology and associated business practices also affect DMOs. Furthermore, the various distribution channels in media have been an issue for DMOs for more than 50 years as new media technologies emerge. DMOs have succeeded in adapting like many organizations did (Hays et al., 2013). Emphasis has been given on relationship marketing and customer focus (Grönroos, 1994), including those through social media, to generate behavioral change. Furthermore, new tactics such as viral marketing have also been adapted by DMOs as a response to the rapid development of social media in particular markets as that of tourism. To not forget that marketing through social media is very similar to how tourism uses social media (Hays, Page, and Buhalis, 2013).

Nowadays, tourists want to be completely involved with the destination they visit. It is essential to create experiences and relevant to the particular place and a link in their minds between the activity and the location to achieve the full advantage of their journey. According to the concept of «experience» Franzoni and Bonera (2019) believe that it is perceived as "something strange" that happens to individuals and is only accessible by visitors who are engaged to it. It is generally approved that individuals create their unique experiences based on "previous experiences, education, values, attitudes and beliefs". In the tourism industry, the experiences are developed through "visiting, learning and enjoying different activities" in the selected destination outside the regular place of tourists' work and residence (Cetin and Bilgihan, 2015; Page and Connell, 2006).

DMOs need to focus on the experiences gathered and the competitive dimension analysis to achieve the fulfillment of visitors' needs and gain a high level of satisfaction. Specifically, DMOs must know travelers' opinions to build their strategy based on actual tourists' recommendations and views (Molinillo, LiébanaCabanillas, Anaya-Sánchez, and Buhalis, 2017; Franzoni and Bonera, 2019) rather than relying on assumed responses. It is incredibly difficult for researchers to explore and interpret what the examinees express in oral, writing, or behavior. To accomplish it, they must look at tourists in the field and ask for their impressions on the product/service at the time they consume it. Therefore, DMOs must be fed with useful information to analyze and estimate visitors' experiences in a specific destination. As a result of information gathering will be the conceptualization of further actions that need to be taken cable to improve and increase the reliability and maintain the increased interest of the destination.

2.5 Destination Management Organizations and Tourist Satisfaction. An important field of studies has become the measurement and evaluation of tourists' experiences (Tung and Ritchie, 2011; Kim, Ritchie, and Mccormick, 2012) and surveys, which are considered a way to gather information concerning the measurement of tourists' experiences and satisfaction of a given destination. It is also supported that a successful evaluation is achieved through tourists' observation in their natural habitat (Franzoni, 2015). Various attributes can contribute to real destination competitiveness. These attributes refer to the variables that influence tourists' satisfaction or dissatisfaction during their vacation (Corte, 2015). In any way, the analysis of the satisfaction survey results can be proved useful to define the future destination promotion activity and identify corrective actions, aiming to maintain, increase or implement the experiences required to increase tourists' satisfaction and, in the end, achieve loyalty. Moreover, another reason for measuring and explaining satisfaction is to perceive the extent to which the suppliers of a particular destination understand and respond to visitors' needs. Additionally, it is a way to identify which elements of the destination's offer need improvement. Undoubtedly, tourists' comments, complaints and suggestions are the most valuable sources for improvements and 
innovations. Consequently, successful destination management can be achieved through various research that measures tourist satisfaction. It is well known that tourist satisfaction influences destination choice, the consumption of products and services, and the decision to revisit (Corte, 2015). Most researchers agree that measuring and evaluating customer's satisfaction in the context of tourism has been part of a process that aims to improve the quality of the product and consequently to improve organization's competitive advantage, increase customer loyalty and succeed word of mouth and therefore develop a strong reputation in the marketplace. Besides, lower transaction costs, improved ability to attract new customers and impact on customer retention are also positive effects of tourist satisfaction. Finally, the tourism industry will benefit other sectors such as retails, transportation, and construction (Angelova, and Zekiri, 2011; Corte, 2015; Aliman, Hashim, Wahid, and Harudin, 2016). As such, DMOs are willing to improve the attractiveness and competitiveness of a tourist destination. Therefore, it needs to focus on experiences rather than just services (Franzoni, 2015; Neuhofer, Buhalis, and Ladkin, 2012; Neuhofer, Buhalis, and Ladkin, 2015).

It is a requirement for DMOs to understand the level and the drivers of satisfaction among visitors and the causes of dissatisfaction. This information is required to inform strategic planning for future tourism development, destination marketing, experience designs and delivery, performance management, and human resource development (Beigpoor Shahrivar, 2012; Aliman, Hashim, Wahid and Harudin, 2016). Visitors' satisfaction can lead destinations to long term success and at the same time, it brings benefits for stakeholders, industry, visitors and local communities. (Fathimath, 2017). Many researchers describe the outcomes of customers satisfaction which are a) word of mouth, b) costumers' complaining behavior, c) brand loyalty, d) continuance, e) recommendation, and f) repurchase intention/repeat visitation (Thusyanthy and Tharanikaran, 2017; Survicate, 2020; Gounaris, Dimitriadis and Stathakopoulos, 2010; Wang, Y. 2016). Various studies in visitors' satisfaction at a specific destination pinpoint that a high level of satisfaction encourages destination revisits, free promotion, and advertisement through word of mouth and financial competitiveness. Many studies argue that satisfaction is a crucial antecedent for loyalty in reviewing and word of mouth (Mostafavi Shirazi, 2016). According to the results of ACSI (American Customer Satisfaction Index), customer satisfaction is related to economic performance. Thus, higher levels of customer satisfaction, lead to increased financial returns in comparison to the competitors. Moreover, satisfied customers are willing to pay more for products and services and support the destination in periods of crisis, increasing the growth of the gross domestic product.

\section{Case Study Area}

Lesvos is an island located in the North-eastern Aegean Sea and belongs to the North Aegean Region. With a total area of $1,636 \mathrm{~km} 2$ is the third biggest island in Greece after Crete and Evia. According to the Hellenic Statistical Authority (2018) data, the island's population is 86,436 residents. Lesvos has a fascinating Mediterranean mosaic of a well-preserved natural landscape with diverse ecosystems and it is a UNESCO Global Geopark for its ancient, petrified forest preserved by a massive volcanic eruption 20 million years ago. The island presents a diversity of man-made and cultural resources. There are six archeological sites and museums, three byzantine museums, and seven more modern history museums. Besides these, there are seven characterized traditional villages. The economy of the island is based on agriculture and services (including the tourism sector). Tourism on the island is not as much developed as in the other islands of the Aegean Sea. Still, the industry faces strong seasonality, small hotels of three or four stars, and tourism products mostly based on sea and sun, although the island offers many resources to differentiate the product and provide authentic activities to its visitors. Table 1 demonstrates the image of tourism in the island from 2010 to 2018 as for the arrivals, the overnight stays and the occupancy in hotels. According to the Hellenic Ministry of Tourism, there are 6,723 hotel beds and 7,084 beds in secondary establishments in 2019.

Table 1. Arrivals, overnight stays and occupancy in hotels in Lesvos from 2010 to 2018

\begin{tabular}{|l|c|c|c|c|c|c|c|c|c|}
\hline & $\mathbf{2 0 1 0}$ & $\mathbf{2 0 1 1}$ & $\mathbf{2 0 1 2}$ & $\mathbf{2 0 1 3}$ & $\mathbf{2 0 1 4}$ & $\mathbf{2 0 1 5}$ & $\mathbf{2 0 1 6}$ & $\mathbf{2 0 1 7}$ & $\mathbf{2 0 1 8}$ \\
\hline Arrivals of foreigners & 43.579 & 50.441 & 46.956 & 62.041 & 76.251 & 90.201 & 53.358 & 65.531 & 67.190 \\
\hline Arrivals of nationals & 59.746 & 58.869 & 48.669 & 48.469 & 46.257 & 41.432 & 38.525 & 47.000 & 45.392 \\
\hline $\begin{array}{l}\text { Overnight stays of } \\
\text { foreigners }\end{array}$ & $\begin{array}{c}308.92 \\
1\end{array}$ & 337.611 & 268.248 & 331.913 & 434.860 & 467.484 & $\begin{array}{c}356.49 \\
6\end{array}$ & $\begin{array}{c}384.02 \\
9\end{array}$ & 437.532 \\
\hline Overnight stays of natives & $\begin{array}{c}178.49 \\
7\end{array}$ & 171.221 & 126.479 & 127.005 & 128.423 & 116.539 & $\begin{array}{c}109.36 \\
7\end{array}$ & $\begin{array}{c}134.51 \\
4\end{array}$ & 122.762 \\
\hline Occupancy rate & $37,0 \%$ & $37,1 \%$ & $28,1 \%$ & $32,4 \%$ & $39,1 \%$ & $39,8 \%$ & $31,0 \%$ & $33,1 \%$ & $35,0 \%$ \\
\hline
\end{tabular}

Source: Insete Intelligence (2020) 
Lesvos as a destination for the last ten years, has faced multiple crises like the economic crisis of the country started back in 2009; the refugee crisis started ago in 2015 and until nowadays has a dramatic effect in the image of the destination, the consequences of Thomas Cook bankruptcy, and BREXIT. Due to all those crises affecting the tourism product, the island did not follow the evolution in those last years. The most interesting element is though, the sustainability of the tourism product that has to offer as the destination gradually managed to overcome all the above crises. As Constantoglou and Prinitis (2020) point out, the island will face a new era of crises because of the geopolitical instability between Greece and Turkey and mostly because of the crises caused worldwide from COVID-19.

\section{Methodology}

The islands of the North Aegean Region have created a Destination Management Organization. The founding purpose of the DMO is tourism planning and management, along with the intra-regional coordination of the stakeholders to propose and implement specific and sustainable policies for tourism. The vision and mission of the DMO is the transformation of the North Aegean islands into a destination of high added value that offers to its visitors' high standard experiences all year round. Through a holistic approach, the DMO will ensure that tourism in the post COVID era will add value to the economy, social fabric, the physical and man-made environment of this island region. Planning, development, and marketing must be based on research and the customer's needs to be effective. Thus, Destination Management should integrate both demand (customer needs) and supply (product and experience). The adaption of a holistic view in destination management will ensure that industry objectives are planned and managed to meet the needs and aspirations of the communities of the North Aegean Region islands and the context unique of the destination. The most important key outcome of holistic destination management is a resilient and robust tourism industry with a dynamic and adaptive product that adapts the visitor's needs and the community as the destination evolves and matures. In this case, primary and secondary research to inform both planning and implementation is crucial and will keep a wellmanaged destination that has to offer relevant products and experiences.

It is the first attempt to conduct visitor satisfaction research on the North Aegean Region islands and, more precisely in Lesvos to the author's best knowledge. The paper analysis the primary results of this research. The tool of this research was a self-completed questionnaire consisting of sixty questions. The questionnaire was in google forms and was distributed to the visitors during their departure from the island's airport in QR code during 1st to 21st August 2019. In this way, visitors could complete the questionnaire even after arrival to the origin-destination and at the most convenient time. According to the Airport's Authorities during that period in 6,976 passengers were departing from the airport. The passengers, older than 18 years old and younger than 65 years old, were approached at random, they were informed of the survey's nature and asked to complete the questionnaire. Six hundred questionnaires were distributed, and 201 filled questionnaires were collected (response rate 33.5\%). In designing the questionnaire, the concerns of the local society, those of the authorities and the stakeholders, and similar other studies were published in journals. The first section of the questionnaire investigates the overall quality of the tourism experience in the island. The second part asks about the visitor's beliefs on the competitive advantage of the destination. In the third part visitors were asked about their perceptions about the island's brand name. In the fourth part they were asked about the level of satisfaction regarding the visit. The fifth part had general questions about the organization of their trip. Finally, in the sixth section, they were asked to give the necessary personal information. The data collected were statistically analyzed using the Statistical Package for the Social Sciences (SPSS) version 22.0. Descriptive statistics were used to investigate visitors' perceptions of the destination Lesvos.

\section{Results}

5.1 Quality of tourism experience. When visiting Lesvos, considering the quality of tourism experience, the first phase focuses on transportation from and to the island. The second question is about the easy access to information about the destination. $78.6 \%$ of the respondents think that they had easy access to the island while $10 \%$ disagreed and 11.4 neither agreed nor disagreed. The information $75.6 \%$ believes that they had easy access to all the information about the destination. 


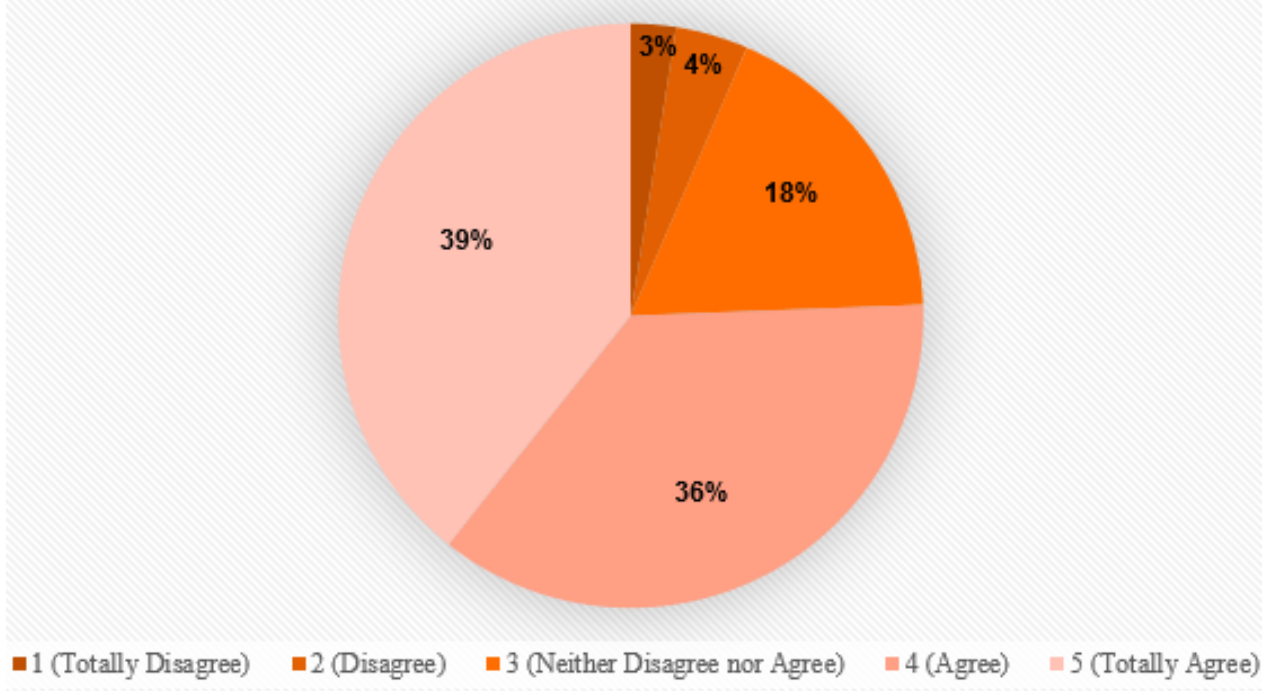

Figure 1. Easy access to information about the destination

Source: Survey Data

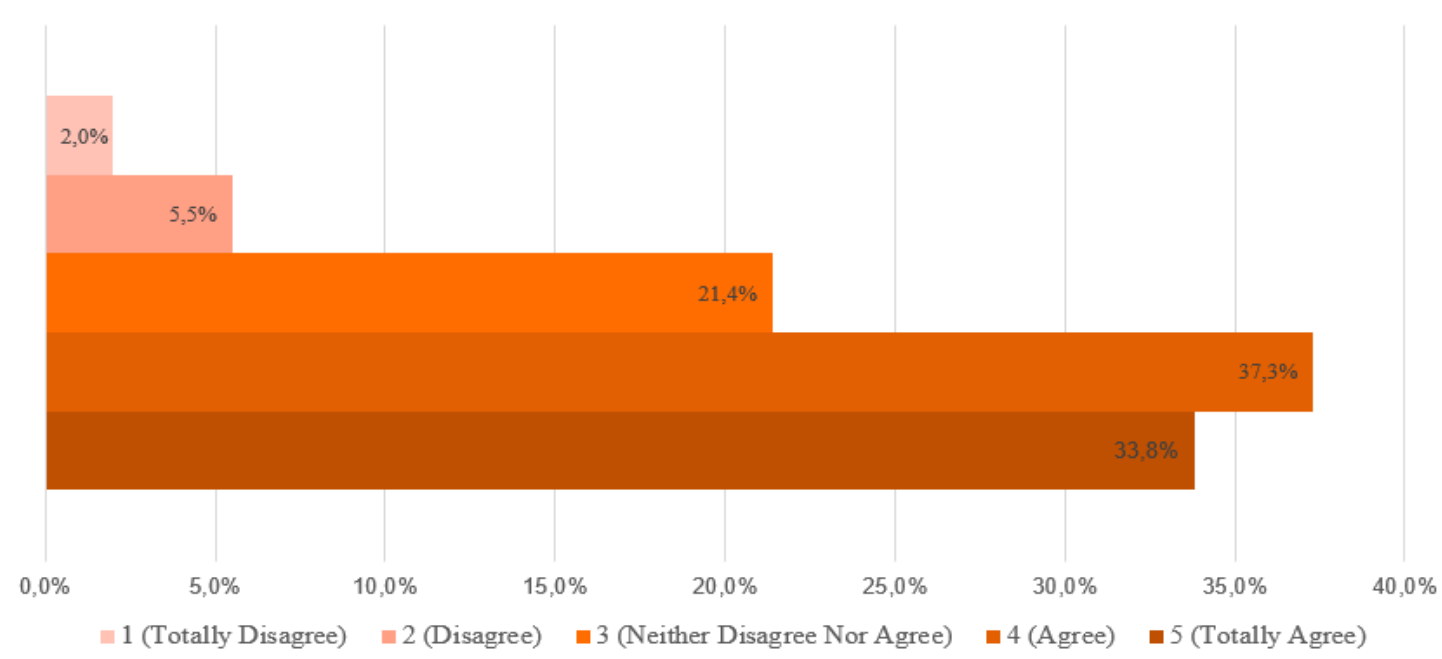

Source: Survey Data

Figure 2. Unique touristic locations, historical and cultural heritage

According to their experience on the island, they (95.6\%) argued that the weather conditions were excellent. A percentage of $71.1 \%$ has felt that Lesvos island has a rich historical and cultural heritage. They also point out the high quality of accommodation (63.7\%), while gastronomy and pure, authentic tastes are also highly rated by $79.1 \%$ of the respondents. Overall, they have declared $(76.1 \%)$ that the island provides high-quality services $(76.1 \%)$. They had a variety of entertainment activities to follow (18.4\%). It is a very interesting point as the respondents believe that the destination meets their needs and prospects, but they had a few entertainment options.

$84.1 \%$ believe that the value for money is very well balanced as the destination's pricing is very good. $68.2 \%$ of respondents have found that the environment is clean. Their perception of the information they had during their visit on the island they believe that it was user friendly (75.2\%). As far as security and safety is concerned, $77.1 \%$ felt safe and secure on the island and only $6 \%$ did not. On the other hand, there is a percentage of $16.9 \%$ who could not decide. 


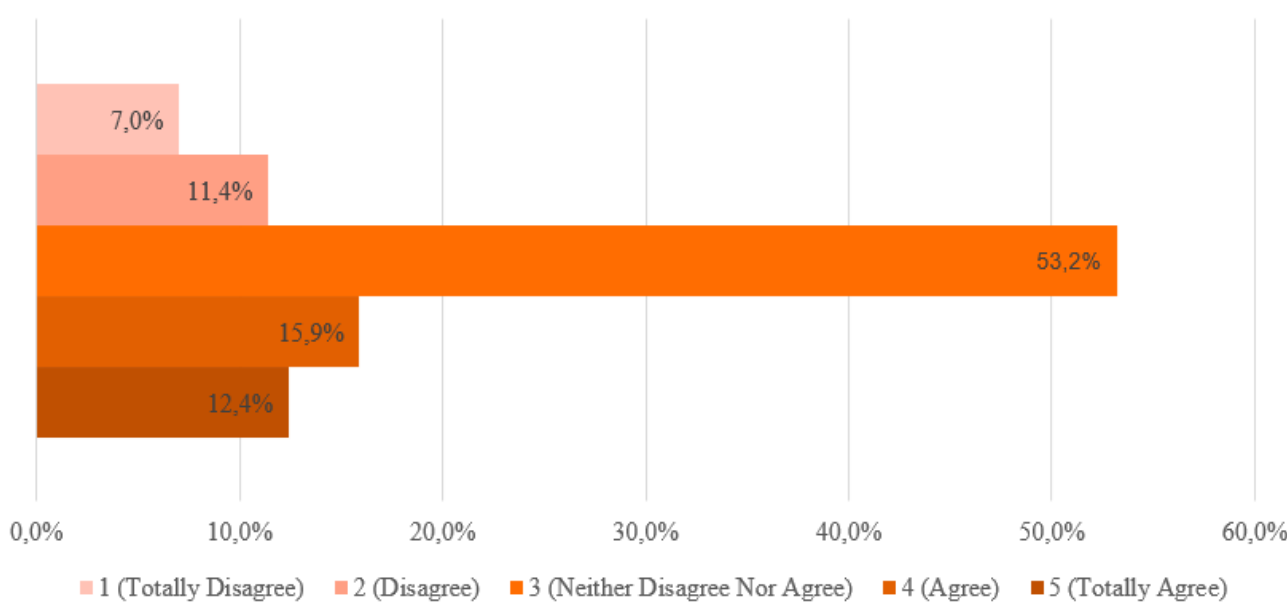

Source: Survey Data

Figure 3. Variety of entertainment activities to participate

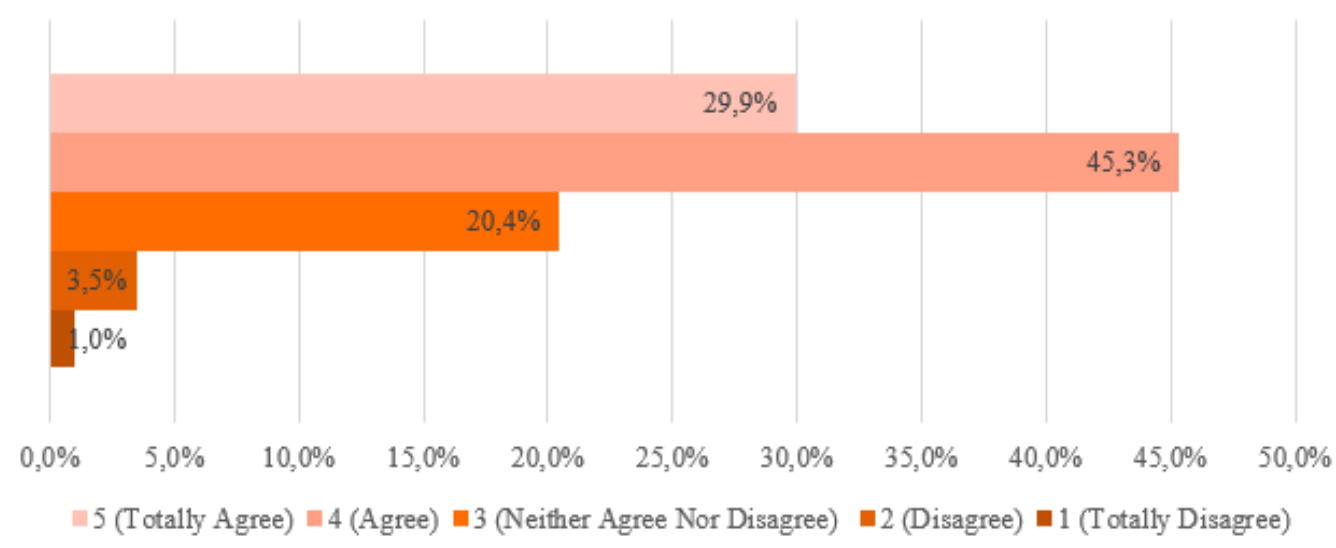

Figure 4. User of friendly information

Source: Survey Data

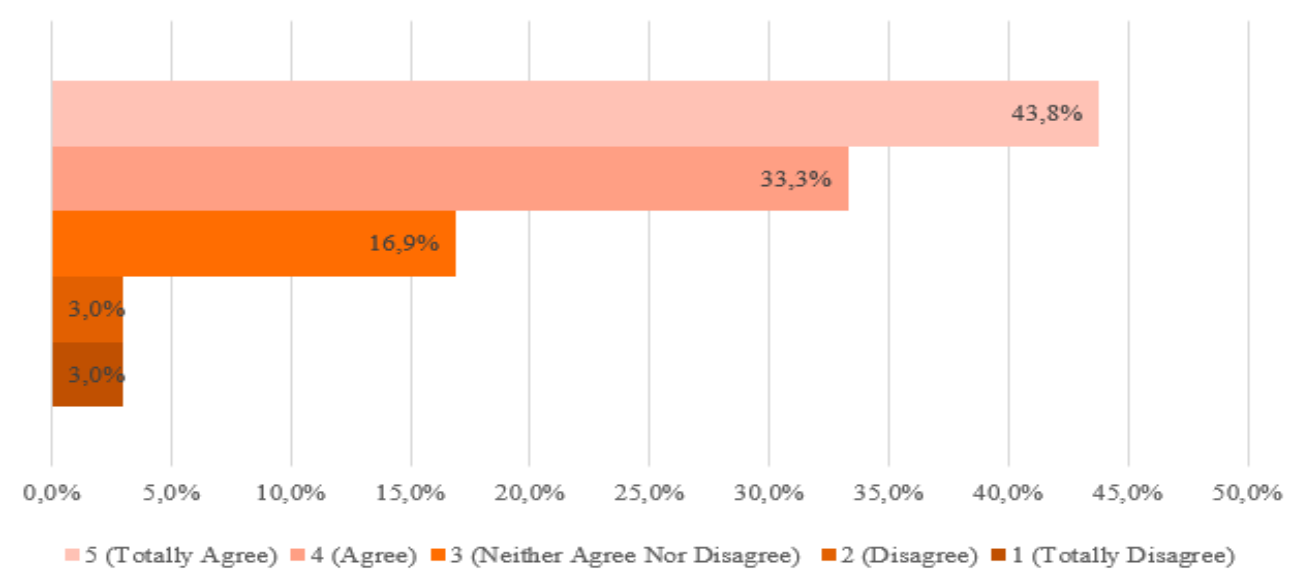

Source: Survey Data

Figure 5. Sense of security and safety in Lesvos

Finally, they have underlined the good communication they had with the local population and they have stated that "the population is friendly and authentic" in a percentage of $81.1 \%$. Only $7 \%$ had a negative perception of communication with the locals.

5.2 Beliefs for the competition of the destination. Due to the tourism industry's developments and changes in consumer behavior, more destinations, more choices of accommodation, and a wide range of activities are now offered to tourists. Every destination offers a variety of products and services to attract tourists. Therefore, it is essential to know its strengths and weaknesses, which will affect the repeat visits and the nature of worldto-mouth communication. 


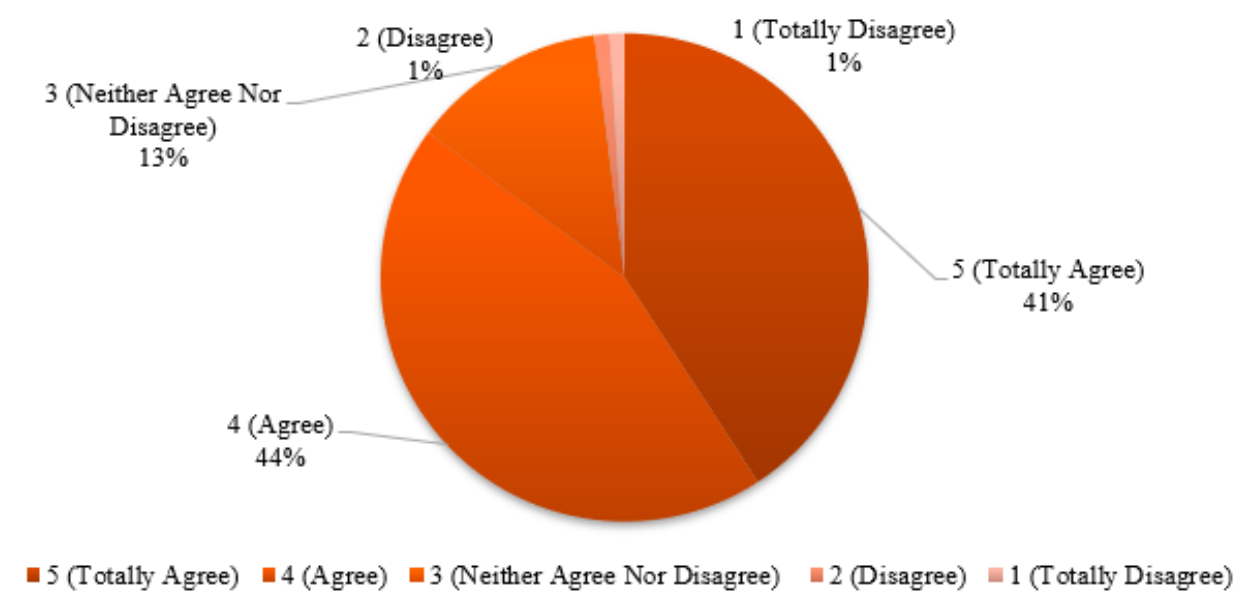

Figure 6. Friendly and hospitable locals in Lesvos compared to other destinations

Source: Survey Data

Moving towards the second part of the research which is concerned with the beliefs on the competition of destination, the following results were gathered. Respondents believe that compared to other destinations Lesvos has better weather conditions $(77.6 \%)$ due to the number of sunny days all year round. They find easy to reach the destination $(64.8 \%)$ where they find unique touristic resources like historical and cultural heritage, local traditions, local cultural and unspoiled natural environment $(66.2 \%)$. They feel that the natural environment is very well preserved at the destination (55.7\%) or well protected (31.8\%) compared to other islands and destinations that they have visited. Additionally, they find locals to be friendly and hospitable in Lesvos compared to other destinations, the $85.1 \%$ supported that the locals were very friendly and hospitable in comparison to other destinations, while almost the $21 \%$ could not state it for definite.

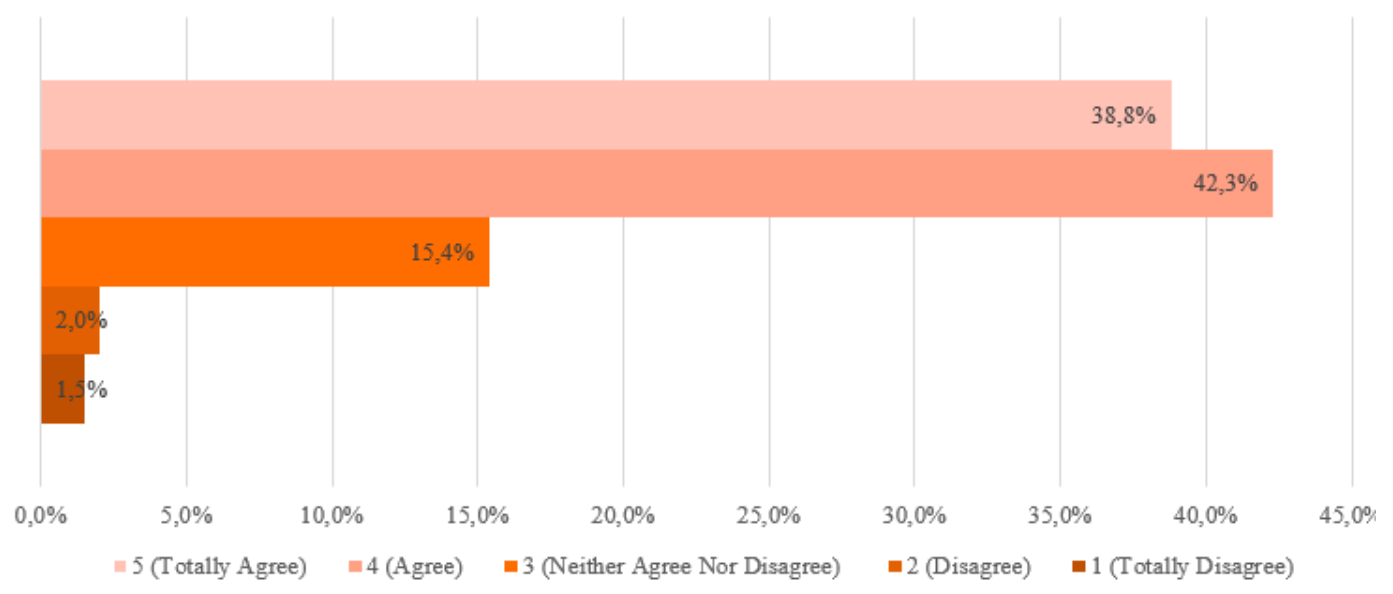

Figure 7. Good communication with local people

Source: Survey Data

Deciding the pricing for the products is no easy task. Price is a crucial factor a customer will consider when making a purchasing decision. Customers are price sensitive and browse through the market for price comparison and choose one that offers the best deal. Therefore, it is supported that when comparing to other destination the prices in products and services are good as the $72.7 \%$ of the participants reveal. Yet, there is a $21 \%$ that was not convinced by the prices.

Taking into consideration the quality of touristic experience in the question about the commitment to provide quality touristic experiences compared to other destinations, it is interesting to see that the $43.3 \%$ was not in the position to classify their experience and for that reason they could not state for sure whether they agree or disagree with the statement. Only the $48.7 \%$, which is not as high as it was expected, argued that they had an excellent touristic experience during their stay in Lesvos. According to the question about the relevance between quality and pricing for all services provided and activities compared to other destinations, the $75.1 \%$ stated that there is a good balance between quality and price for the products and services offered, although there is a $20.4 \%$ which is not certain about this balance. One of the most important factors that keeps the visitors visiting the destination is the security of the place. A percentage of 59.7\% answered that they felt safer and more protected in Lesvos rather in other destinations but there is also a 33.3\% that could not give a straight 
answer. Finally, what it is also examined in the research is whether the interconnections between Lesvos and Intermediates, like travel agencies and airline companies, promote Lesvos Island as a touristic destination. A $55.7 \%$ agreed that there is a great interconnection, while the $33.3 \%$ either agreed or disagreed and the $8 \%$ disagreed with the statement. This question shows that the island is not a destination well promoted by travel agents through Europe and this is also supported by a previous question that shoes that most of the respondents travel alone or with their families but the least of them travelled with a group although the survey was conducted during August.

5.3 Destination branding. The destination branding is an important element in tourism due to the role that it can have in the intangible nature of consumer decisions (Pike et al., 2019). Due to the intangible nature of branding (Pike et al., 2019) and the dynamic nature of its perception over time and space (Kim et al., 2019), the measurement of destination image should reflect both cognitive and emotional aspects (Byon and Zhang, 2010). Destination branding is the foundation which creates a positive image and unique identity of every place. Brands refer to almost every aspect of tourism products and services, tourist behaviors, choices, destination images and should be promoted through internal and external marketing efforts. This is particularly important in-service industries, where customers' experiences are created by interaction with employees and locals. In terms of tourism destination branding, the role of local people is essential.

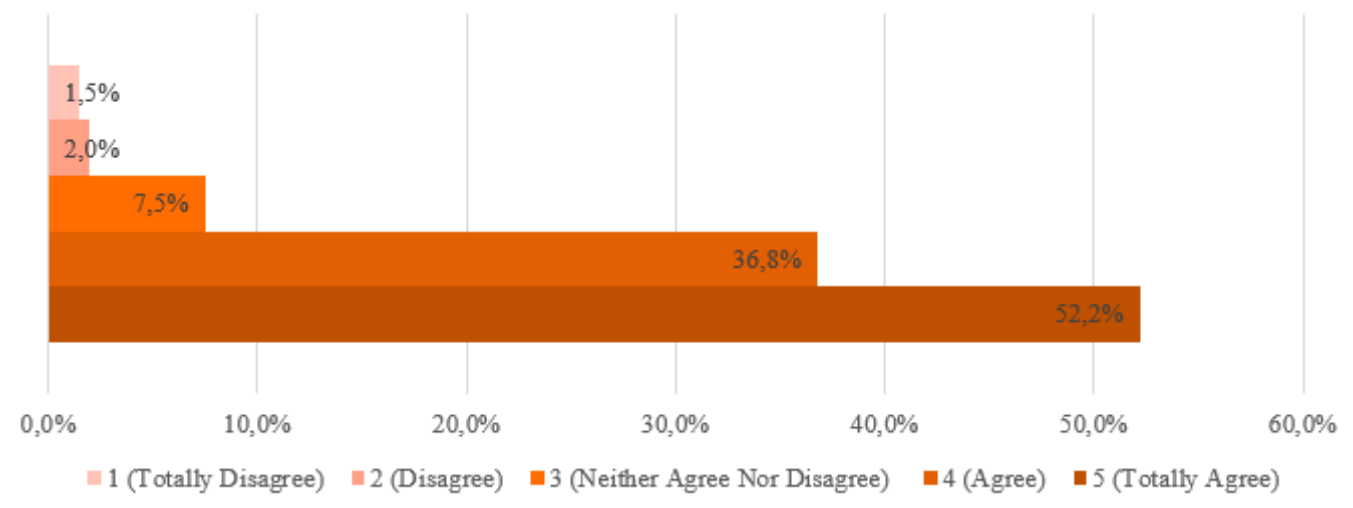

Source: Survey Data

Figure 8. The destination of Lesvos is peaceful, secure and pleasant

When visitors come to a tourism destination, they encounter not only specifically designated service employees but also the general local population. In the research, 92.6\% argued that Lesvos had many friendly locals and only a small percentage disagreed. Destination branding can benefit significantly through smart and wellchosen associations with the landmark, raising not only awareness but helping to grow the brand and enhance its story. The $84.6 \%$ argued that the Island had beautiful landmarks that aimed to do more than just raise awareness; it can help to create a mutually beneficial glory for both the brand and the landmark.

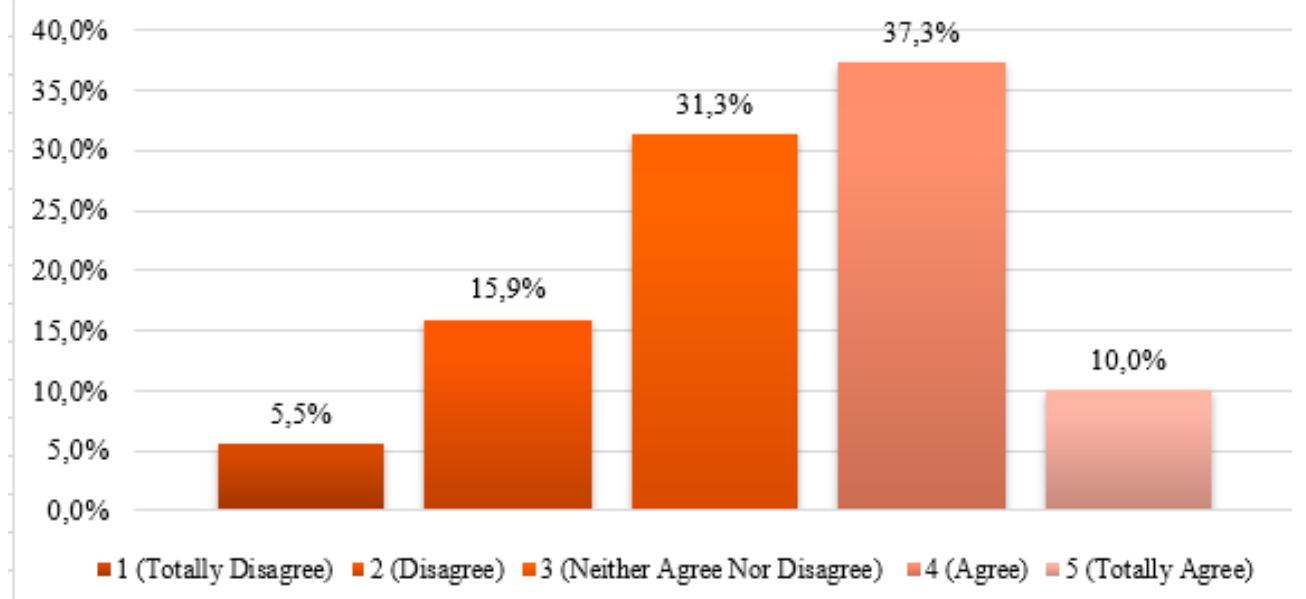

Figure 9. The destination of Lesvos has high hygiene standards

Source: Survey Data

As it is already mentioned, security and safety play an important role in tourism and in fact it could be another aspect that adds to the creation of an unforgettable brand. An 89\% supported that Lesvos is a peaceful, secure and pleasant destination both for families (88.6\%) and couples (81.6\%) and it is mostly suitable for relaxing holidays as the research affirmed (93.1\%). 


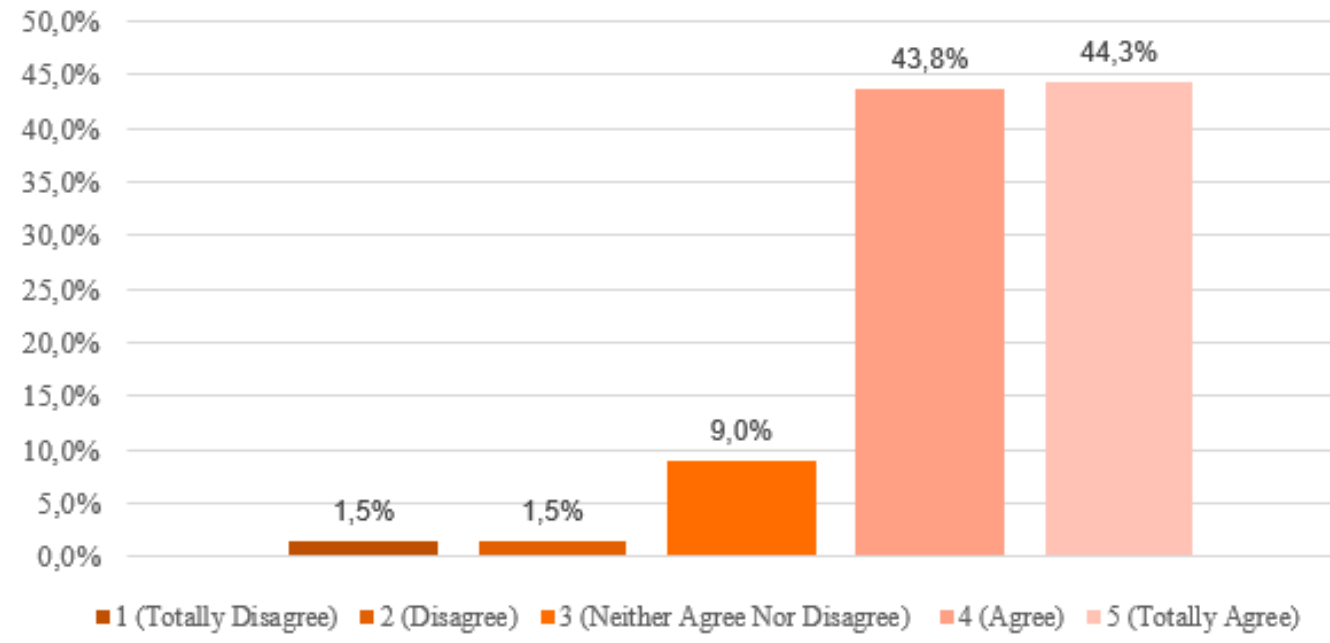

Figure 10. The destination of Lesvos is authentic

Source: Survey Data

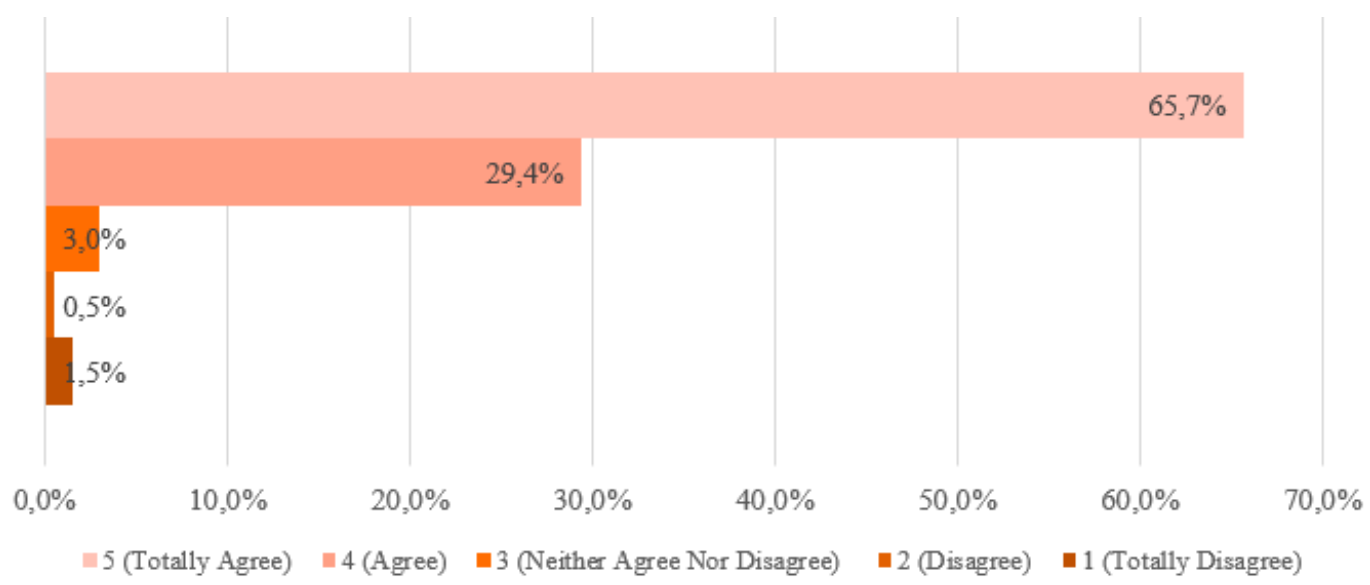

Figure 11. Experience appraisal

Source: Survey Data

Yet, measures should be taken to increase hygiene standards, which leads to the increment of tourists' arrival. $31.3 \%$ believed that steps had not been taken properly and the 30.8\% supported that they are low. Only $47.3 \%$ agreed that Lesvos as a travel destination follows high hygiene standards.

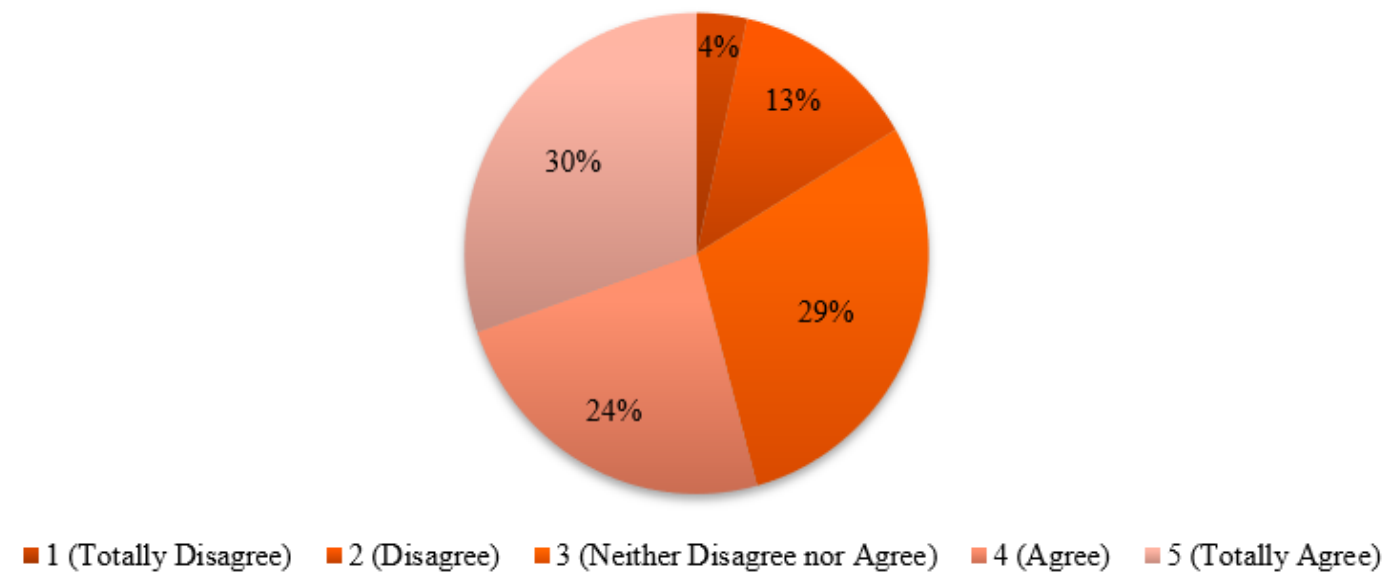

Figure 12. The destination of Lesvos is very familiar to me

Source: Survey Data

Additionally, destination brand authenticity directly influences recommendation intention and indirectly influences revisit intention. Thus, $88.1 \%$ of the survey participants believed that Lesvos is an authentic destination and the 191 out of 201 in total visitors participated in the research had a positive experience in 
Lesvos. However, 35.3\% did not feel that Lesvos offer an awakening experience in comparison to other destinations.

5.4 Awareness of the destination. Awareness is a term that is commonly used in consumer behavior. It relates to the brand or product that first comes to mind measured by the unaided recall. This research has operationalized awareness of whether an individual had heard or recognized a destination by name or the destination that first comes to mind when considering taking a trip.

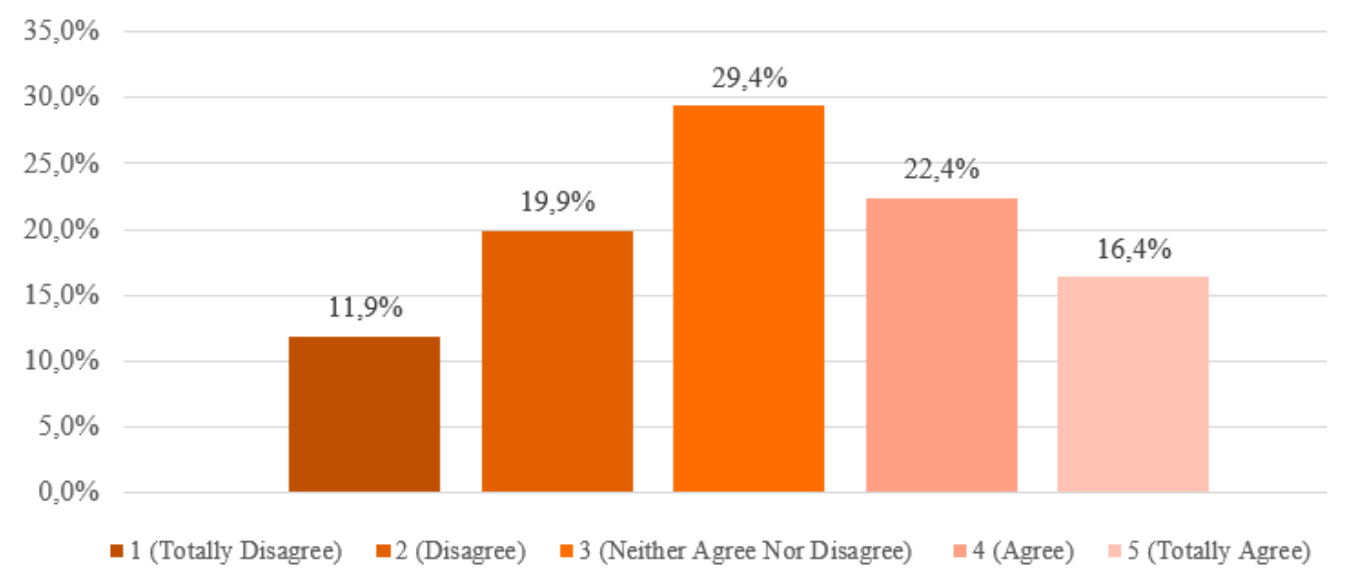

Figure 13. The destination of Lesvos came first to mind when compared to other destinations

Source: Survey Data

Therefore, answering the question if the destination of Lesvos is very familiar to them, the results showed that the $54.2 \%$ were very familiar with Lesvos as a percentage of almost $30 \%$ were repeaters as seen in the previous question, the $29.4 \%$ had neither positive or negative information to provide, and $16.4 \%$ that was not familiar to Lesvos. In the question whether Lesvos is coming first to their mind when compared to other destinations exhibits that only a 39\% recalled Lesvos when they were thinking of destinations, the $32 \%$ disagrees or disagrees, $29 \%$ neither agrees or contradicts, meaning that they cannot consider Lesvos as the first destination that came in their mind when was compared to other places. Given the above results, the destination must plan more specific, practical, accurate and well-promoted media campaigns to be more recognizable. Another interesting part that is covered in this section is the extent to which Lesvos's products are well known. Understanding the tourist product is a prerequisite for effectively marketing a destination or a tourist business. Tourist products have a complex nature. They consist of numerous components in which each one is playing a distinct functional role in categorizing tangible and intangible elements. These components complement each other and enable tourists to be engaged in an activity either in one or multiple destinations. Additionally, these elements allow facilitating the transition to the destination and social reproduction during the trip. It is good to know what products the tourists consume when they arrive in Lesvos and whether they have managed to satisfy their primary or secondary needs. $66.1 \%$ was aware of the local products that are produced in Lesvos, such as Olive oil, Ouzo, Graviera and Feta. $16.9 \%$ of participants did not know any of the above-mentioned local products and $17,4 \%$ could not provide either positive or negative information.

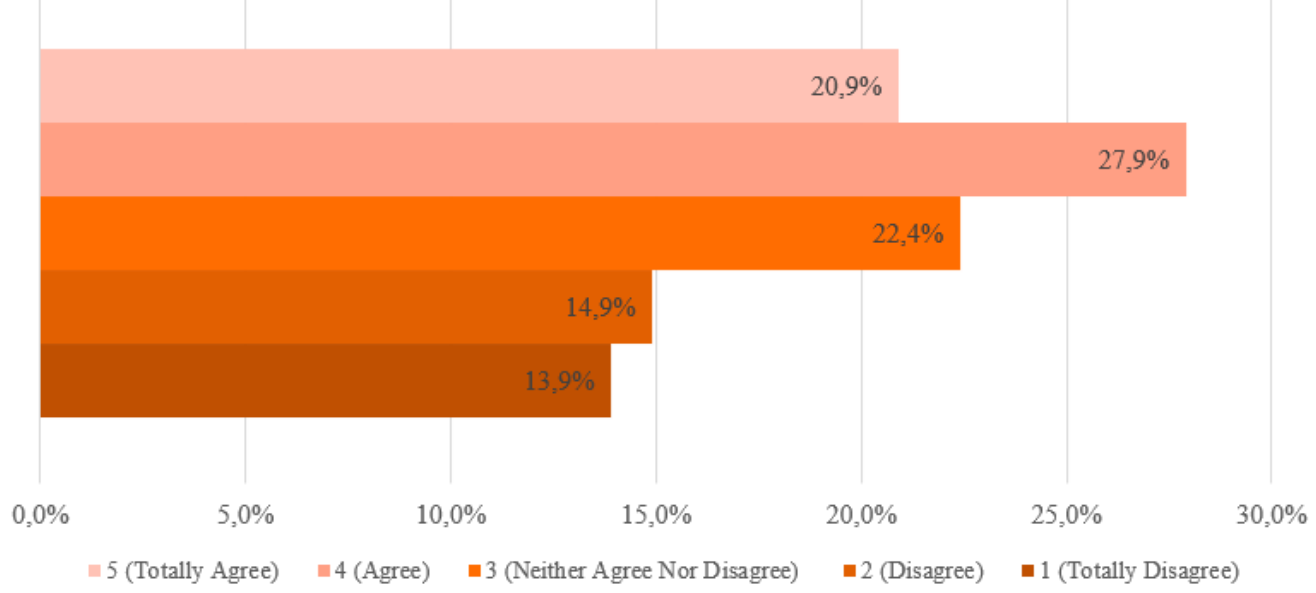

Source: Survey Data 
UNESCO recognizes Lesvos island as Global Geopark. The analysis reveals that less than $50 \%$ were aware of this unique product or visited the site. A $28.8 \%$ did not know Lesvos for this unique tourist product and a $22.4 \%$ did not provide valuable information for the given question. Additionally, Lesvos is not known for the hiking activities that are provided in the countryside since the $33.35 \%$ were not informed about the event and $31.3 \%$ did not give any information, either negative or positive, to support the research. Only a small number of visitors, $35.4 \%$, knew about those kinds of events.

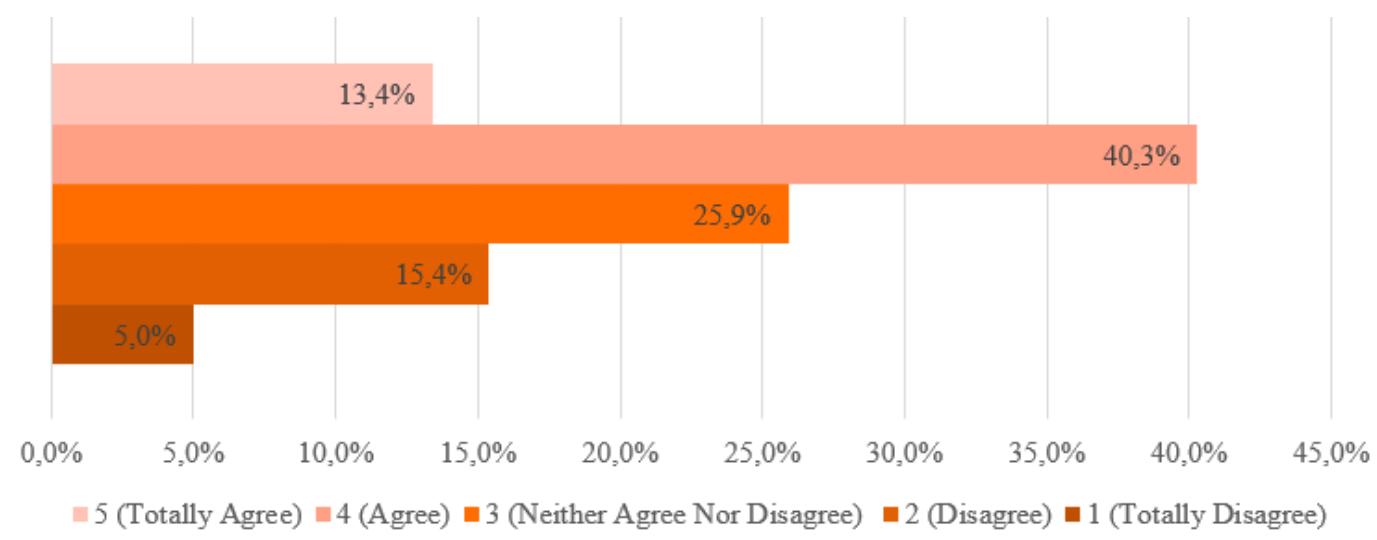

Figure 15. The destination of Lesvos is well known for its cultural heritage

Source: Survey Data

The destination of Lesvos is well known for its cultural heritage. The $53.7 \%$ were totally informed about the cultural heritage of Lesvos, a $20.4 \%$ did not know anything about the rich treasure of the island while the $25.9 \%$ did not give any information to evaluate the question.

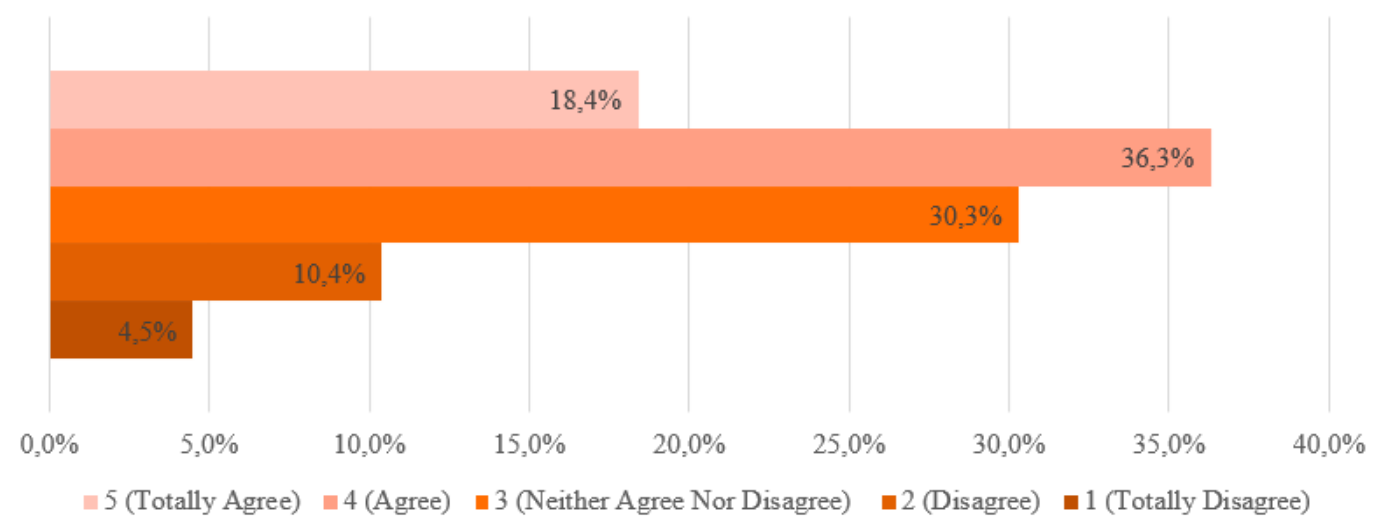

Figure 16. The destination of Lesvos is well known for its authenticity

Source: Survey Data

The research also examined the extent to which Lesvos is known for its authenticity. Authenticity is a complex idea, different for almost every individual, and it is associated with the natural and man-made environment. Authenticity is becoming an increasingly valuable commodity in the tourism industry, as more and more tourists seek to immerse themselves in local cultures and environments. The research showed that at least half of the participants (54.7\%) believed that Lesvos is an authentic destination. On the other hand, the number that did not think this reaches $15 \%$, and $30 \%$ cannot provide valuable information. 


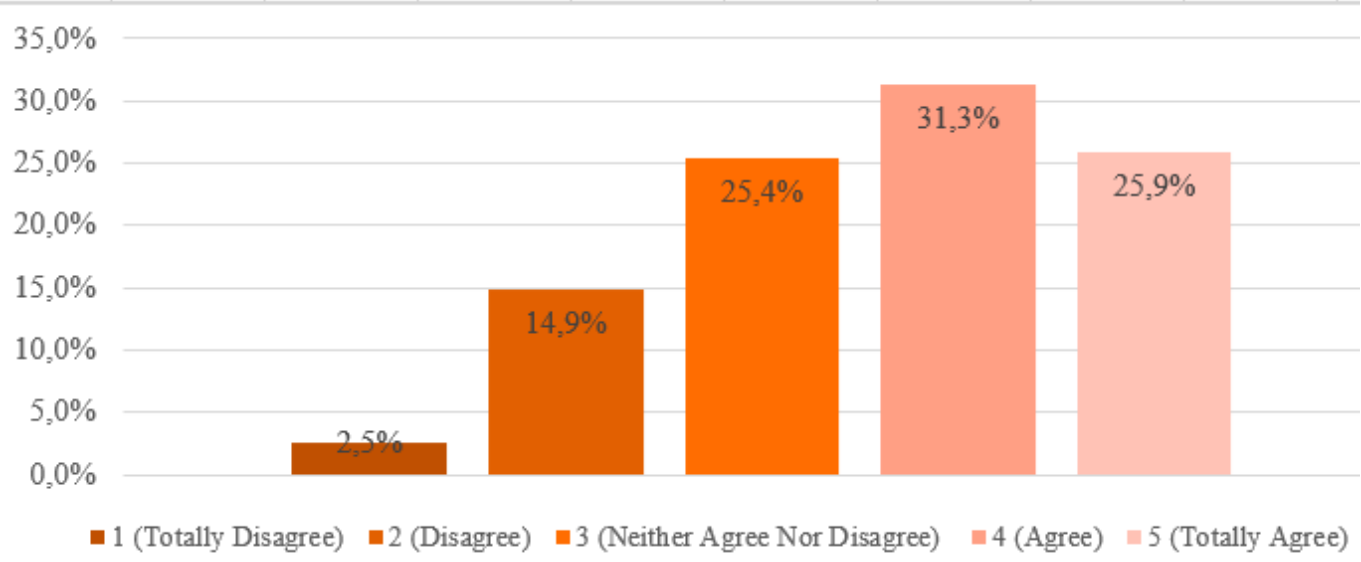

Figure 17. The destination of Lesvos is well known for the refugee crisis of 2015

Source: Survey Data

Furthermore, $57.2 \%$ argued that it has adequate knowledge about the island and $17.4 \%$ did not. An increased number of participants, $25.4 \%$, did not provide any positive or negative information. Finally, it is interesting to notice that most of the participants $(90.6 \%)$ knew Lesvos because of the refugee crisis in 2015. Their willingness to visit the island did not change as they have stated, despite what they have heard on the news or what they have seen in the social media.

5.5 Tourist Satisfaction. $76,1 \%$ of the participants agreed that Lesvos destination is better than expected, while $18.9 \%$ were not positive or negative and only $5 \%$ did not believe that Lesvos destination was better than it was expected. In general, 160 tourists out of 201 argued that Lesvos Island had more advantages than disadvantages and only 43 of them were unsure about the destination. In general, 181 answered that they were delighted with their vacation to Lesvos, 11 out of 201 were unsure and only nine were not satisfied with their visit in Lesvos.

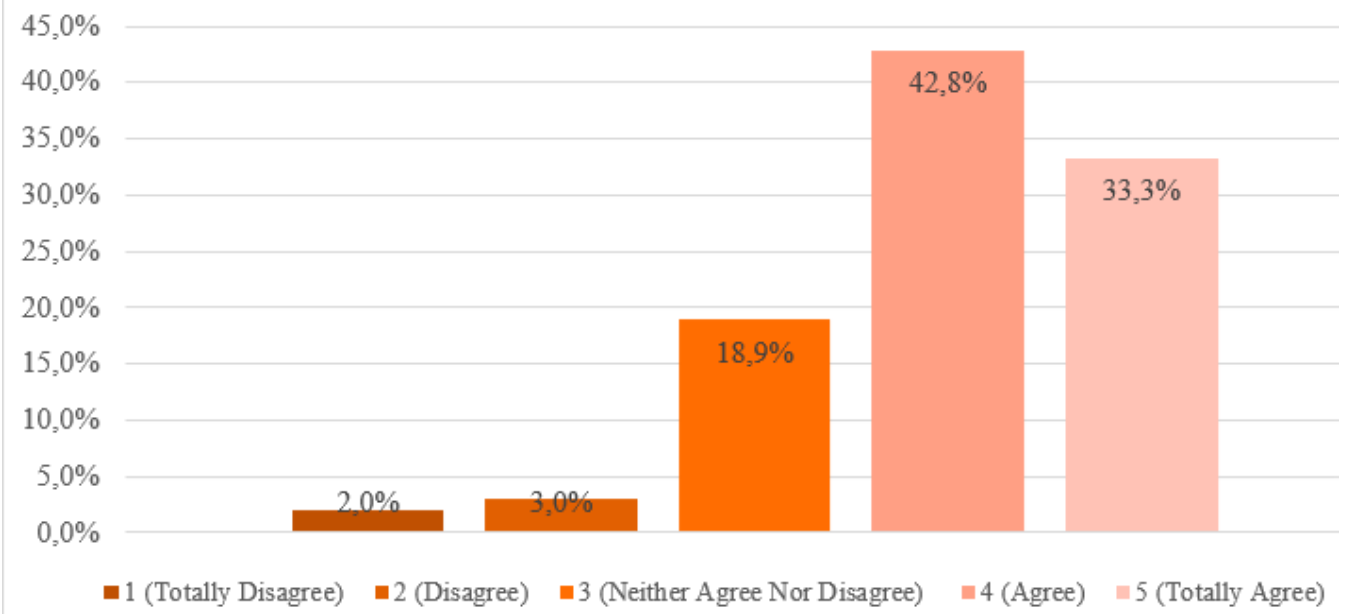

Figure 18. The destination of Lesvos is better than expected

Source: Survey Data 


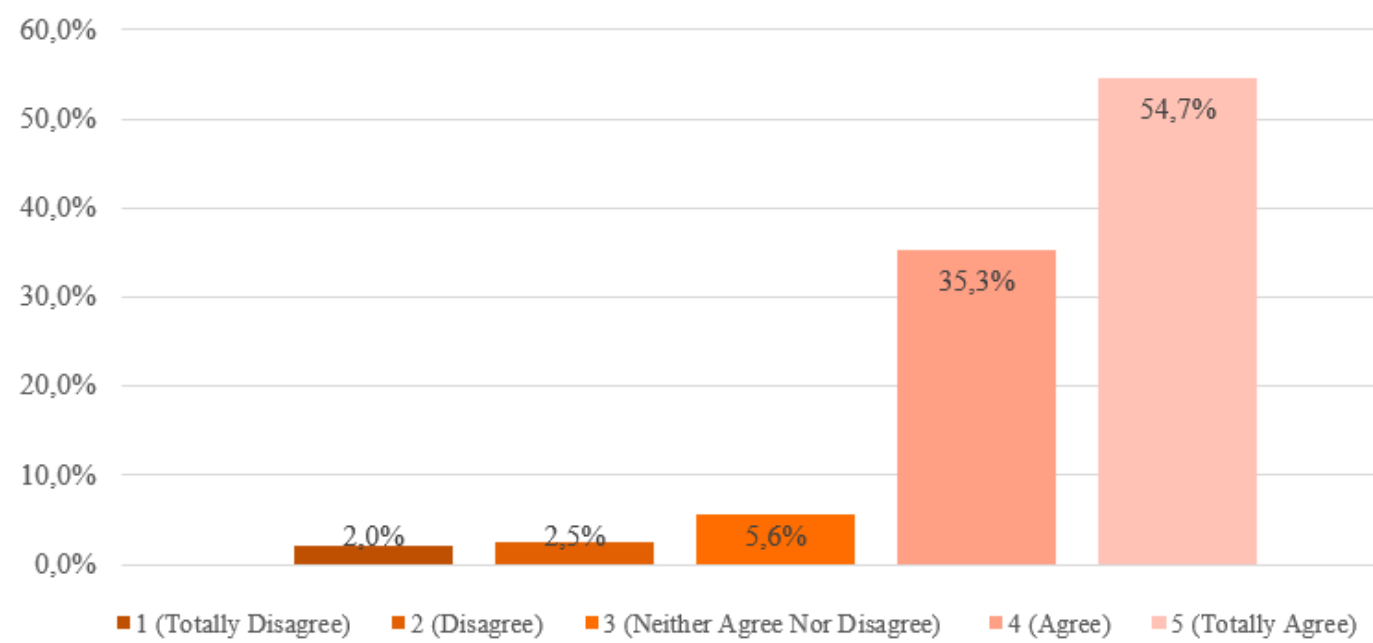

Figure 19. General satisfaction level

Source: Survey Data

5.6 The respondent's profile. The analysis shows that $58.8 \%$ of those who participated in the research were female and only $37.7 \%$ were male, while a small amount preferred not to say. Almost the half of them (47\%) was over 45 years old, $18.7 \%$ belonged to the age group $35-44,18.2 \%$ to the $15-24$ and $16.2 \%$ to the $25-34$ age group. Regarding visitors' nationality, it is identified that from the 201 participants, 63 (34.2\%) were Greeks, 59 (32.6\%) came from the Netherlands, 17 were Danish, 12 British, and five arrived from Belgium. Other nationalities monitored were the Australian, Czech, German, Italian, Norwegian and Swedish. Regarding the educational background from the 191 responses the $48.2 \%$ owned a bachelor's degree, $24.6 \%$ attended the high school, $21.5 \%$ had a master's degree and $5.8 \%$ a $\mathrm{PhD}$ degree. The $38.8 \%$ argued that the family income exceeded the 40,000 Euros, the $29,5 \%$ belonged in the group between 20,001-40,000, the family income of the $24,6 \%$ was between $10,001-20,000$ and finally only the $7.1 \%$ had income less than 10,000 Euros. Yet, $77.2 \%$ of those who visited Lesvos are employed and $10 \%$ only were unemployed. Among the visitors, there is a percentage that is also retired, students, businessmen, etc.

Table 2. Respondents' Profile - socio-demographic information

\begin{tabular}{|c|c|c|}
\hline \multicolumn{2}{|c|}{ Demographics } & Percentage $(\%)$ \\
\hline \multirow{3}{*}{ Gender } & Male & 37.7 \\
\hline & Female & 58.8 \\
\hline & Prefer not to say & 3.5 \\
\hline \multirow{4}{*}{ Age } & $15-24$ & 18.2 \\
\hline & $25-34$ & 16.2 \\
\hline & $35-44$ & 18.7 \\
\hline & $45+$ & 47.0 \\
\hline \multirow{8}{*}{ Country of Residence } & Australia & 3.8 \\
\hline & Belgium & 2.7 \\
\hline & Great Britain & 6.5 \\
\hline & Denmark & 9.3 \\
\hline & Germany & 3.8 \\
\hline & Greece & 34.2 \\
\hline & The Netherlands & 32.0 \\
\hline & Poland & 1.6 \\
\hline \multirow{4}{*}{ Education } & High school & 24.6 \\
\hline & Bachelor & 48.2 \\
\hline & Master's Degree & 21.5 \\
\hline & $\mathrm{PhD}$ & 5.8 \\
\hline \multirow{4}{*}{ Total income } & Less than $10.000 €$ & 7.1 \\
\hline & $10.001 €-20.000 €$ & 24.6 \\
\hline & $20.001 €-40.000 €$ & 29.5 \\
\hline & $40.001 €$ or more & 38.8 \\
\hline \multirow{5}{*}{ Employment status } & Unemployed & 10.2 \\
\hline & Employed & 77.2 \\
\hline & Retired & 4.6 \\
\hline & Student & 2.8 \\
\hline & Other & 5.1 \\
\hline
\end{tabular}

Source: Survey Data 
5.7 General questions. Most of the tourists visited the island (39\%) have stated that they are travelling twice a year, $27.5 \%$ are travelling only once, $20 \%$ three times and the rest more than three times a year.

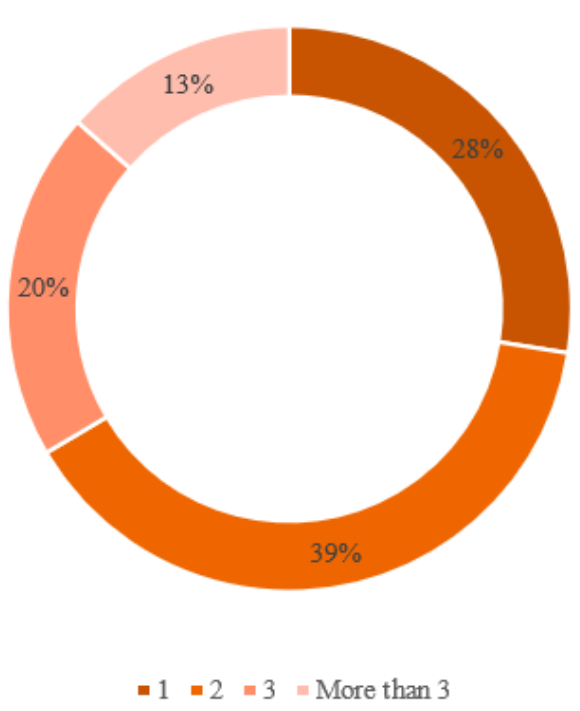

Figure 20. In general, how many times you go on vacations throughout a year

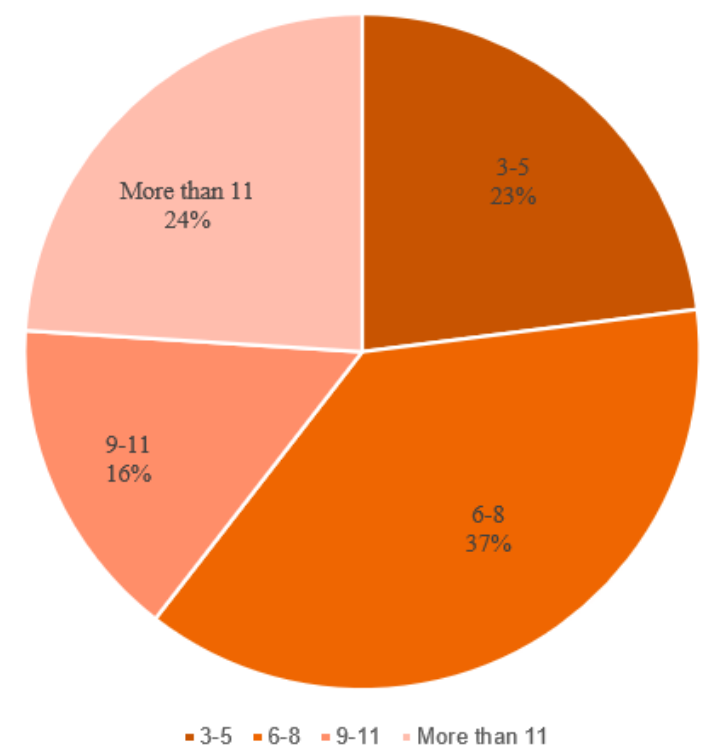

Figure 21. How many nights do you stay?

Source: Survey Data

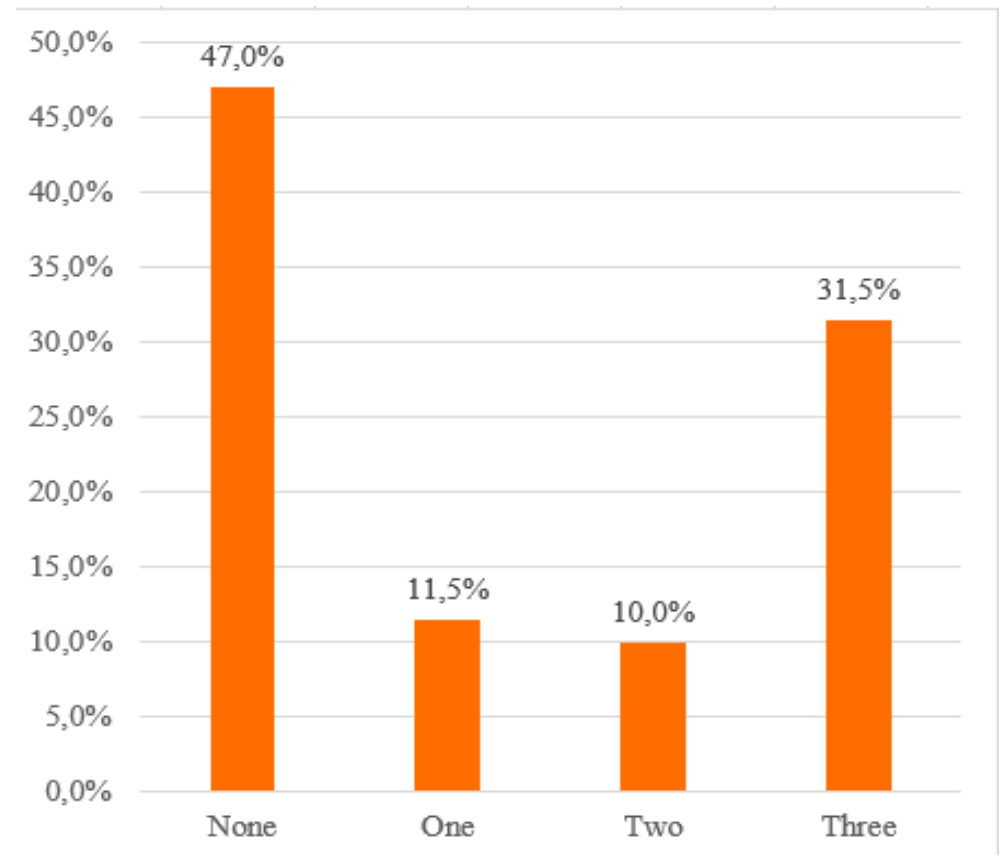

Source: Survey Data

Figure 22. Amounts of times you have visited before the island of Lesvos 


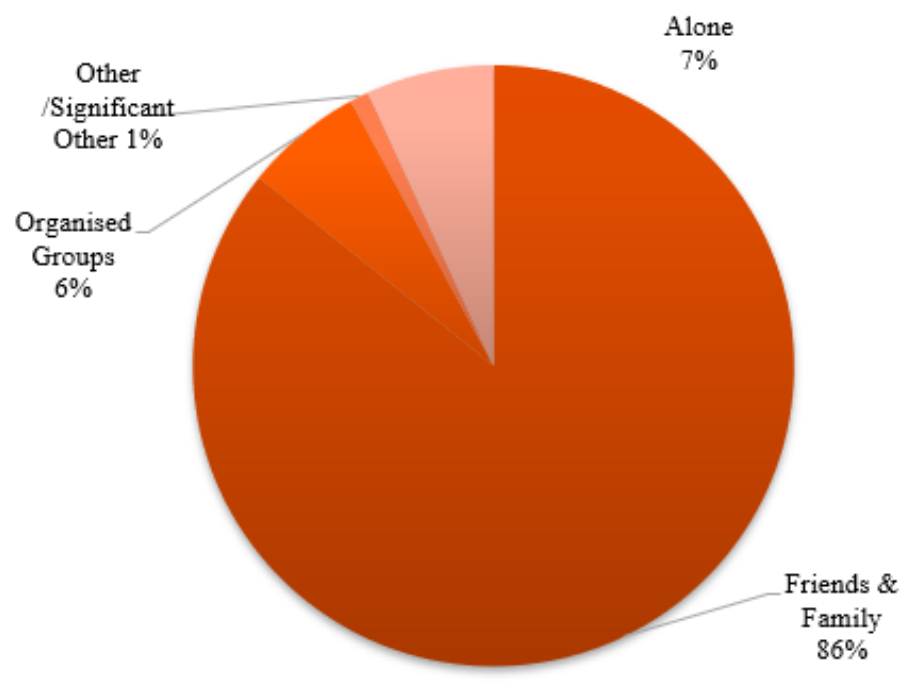

॥ Friends \& Family $₫$ Organised Groups $₫$ Other/Significan Other $₫$ Alone

Figure 23. Who/Whom accompanied you in your holidays (\%)

Source: Survey Data

Out of the 201 given answers, $39 \%$ stated that they are going on vacation twice a year, while $27.5 \%$ one time a year only. $20 \%$ of the total were these people going on vacation three times in a single year and $13.5 \%$ more than three times a year. The $37.5 \%$ stayed for six to eight nights, $24 \%$ more than eleven nights and $23 \%$ three to five nights. It is only $15.5 \%$ that preferred to stay from nine to eleven nights. According to the research, the results showed that $49 \%$ of participants have never visited Lesvos before. $31.5 \%$ have seen Lesvos for more than once, $11.5 \%$ one time and $10 \%$ twice. Most of the respondents, $84.9 \%$, visited Lesvos with friends and families and a low percentage either alone (6.8\%) or with organized groups (6.3\%). According to their stay, most of them (77.8\%) have stayed in the Municipality of West Lesvos in areas like Molivos, Eftalou, Petra, Anaxos, Eresos, Sigri and the rest in the Municipality of Mytilene.

Most respondents have chosen to stay in hotels (53.6\%), while $20.6 \%$ have stayed at rented rooms and $16 \%$ at friends and relatives. Yet, it is noticed that visitors also selected to rent through AirBnB in a percentage of $5.2 \%$ while others stayed at rented apartments $8(4.1 \%)$ and few of them at their own second homes (3.6\%). It is vital to identify the main reason for visiting the island and tourists the island attracts. Therefore, it is observed that $32 \%$ of the study's participants came to Lesvos for leisure. Also, $25 \%$ visited Lesvos due to its natural beauty and $17 \%$ for visiting friends and relatives. Cultural tourism is gradually becoming popular in Greece and Lesvos. Thirty-four participants (17\%) arrived in Lesvos to visit cultural attractions, while 20 of the total participants (10\%) travelled for spiritual or religious purposes. The tourism sector aims to cater to the needs and preferences of all types of tourists, and it seems to consider specific areas of their interest. Consequently, the different tourist attractions identified from the research are bird watching, ecotourism, hiking, windsurfing activities, and sports or business.

\section{Conclusions, Discussion and Recommendations}

The vision of the North Aegean Region DMO is to create and establish a competitive strategic framework for tourism that will deliver a clear, strong and attractive image of the destination. Branding, positioning and targeting of the tourism product are necessary. Suppling tourism products of high added value is a significant condition for a competitive advantage to be created and promoted. Sustainable development should ensure businesses economic viability, the protection of the island's natural and cultural environment, and social integrity. Product portfolio management, together with targeted promotion campaigns, will have as a result, the leverage of the tourist traffic. Sustainable tourism development will increase employment and revenue for the destination and the enterprises. The main objective of this study undertaken by the DMO of the North Aegean Region is to gain knowledge from the destination's visitors. More precisely, to take answers on fundamental questions about the visitor's profile, their beliefs on the quality of the experience at the destination, their perception of the competition and their image about the island and their satisfaction levels after their visit. Data gathered will be used to integrate tourism planning to be rational, tourism policies to be sustainable and realistic and management to be practical and relevant with the objectives initially pointed out from planning. It will be the base for tourism in the island to be sustainable and resilient through time and space. Necessary 
research restrictions were the period that the research took place during August 2019. August is the central touristic time for the island and Greece in general. This research should be ongoing through the years and yearround for the DMO to be able to see changes in attitudes and the image of the destination and to be able to draw meaningful conclusions and in policies that lead to sustainable and resilient tourism policy.

About the profile of the visitors, most of the participants of the survey were middle-aged women. Lesvos is attracting Greek tourists but also Dutch, British and Belgians. They all have a perfect educational profile with a BSc or higher together with a high income. Most of them are travelling for vacation more than twice a year $(82.5 \%)$ with their friends or families and they stay for more than six nights at the destination, which means that the island attracts well-educated tourists with high income. The most exciting finding is that 53\% are repeaters since they have visited the island before more than once, while 31,5\% have visited the destination more than twice. That means that the destination has a high degree of loyalty. They prefer to stay in wellestablished micro-destinations of the island and hotels. They are also attracted by the human and cultural capital of the island, as they have stated. According to the quality of the experience, they affirm positive in transportations means and services. They have a very positive image of the natural and cultural capital of the island, but they are not satisfied with the information they had about entertainment activities that they could attend. They also feel safe and secure at the destination an aspect extremely important for Lesvos as the island's image, especially on these two issues, is damaged after the refugee crisis.

As for the competitive advantage of the destination they strongly believe that this is oriented by the authenticity of the natural and cultural environment, the local people and their traditions. The value for money is well balanced. Although they have an overall very positive experience and believe in the authenticity of the destination they underline with their answers that the island is not well-promoted by travel agents in their countries of origin thus, it is not the first that will come in their minds when thinking about island destinations. On the contrary, they are aware of the local products like ouzo, feta and olive oil. Interesting also is that almost have of them know that Lesvos is a UNESCO Global Geopark and they have visited the site. Efforts should be made here for stakeholders to work more closely together to create unique touristic products. It is extremely critical to rebrand the destination from the distorted and inaccurate image created by the refugee crisis worldwide. Lesvos as a destination has loyal tourists of high educational level and income that, despite the crisis that the tourism product has been through those last five years, are repeating their travel to Lesvos. They strongly support destination authenticity compared to other island destinations and its natural and cultural capital. What island destination management should do is together with the relevant stakeholders to carefully study the island's visitors' perceptions and compose and promote unique products and experiences. At the same time, weaknesses of the destination indicated by the survey should be taken into serious account from the $\mathrm{DMO}$, tourism authorities and the stakeholders. Issues concerning information availability or access to information about events that visitors might be interested in attending, accommodation quality (that needs private investment) and quality products and experiences in the destination that has to be properly promoted are the most interesting findings of the pathogeny of the tourism product of the island.

The rapidly spreading of the COVID-19 pandemic has wreaked global catastrophes. The COVID-19 pandemic has halted mobility globally on an unprecedented scale, causing international tourism neoliberal market mechanisms to be severely disrupted as noted by Ioanides and Gyimothy (2020). The impact of this pandemic to the tourism supply chain and to all those related to the visitor economy on a local, regional, national or global level, have suspended operations and now are trying to restart in conditions of extreme uncertainty. One out of ten people at a global level is working on the tourism sector, meaning that the impact of COVID-19 on the labor force of the sector is devastating. Many destinations that were mainly depended on tourism are strangling to find solutions for the future. Indeed, the sustainable development model has mostly failed to address the 21st century's challenges.). COVID-19 can be seen as a result of neoliberal globalization and timespace compression (Higgins-Desbiolles, 2020) and is forcing expansion in human consciousness that will make humankind better able to address global problems (Galvani, Lew and Sotero Perez, 2020). Travel and tourism should adopt the expansion and awakening of global consciousness as a fundamental and transformational value in the products and experiences it offers. The resilience of growth in international tourism numbers and the capacity of tourism to rebound from the crisis has long been recognized (Hall, Scott and Gossling, 2020) but the essential point is tourism to restart more sustainably by enhancing our knowledge of the world, our sense and appreciation of environmental beauty, and by qualitative and authentic improvements of places(Galvani, Lew and Sotero Perez, 2020). Lesvos and the islands of the North Aegean Region have never been a top-rated touristic destination. Here Sustainable Goals can find suitable soil to grow. Destination management in these islands must promote the authenticity of the natural and cultural environment and to create experiences of high added value for the visitors and the locals. 


\section{Acknowledgements and Research Funding}

ELORIS S.A. is the development agency of the North Aegean Regional Government and is funded by the Ministry of Development and Investments through the North Aegean Special Purpose Development Program for the creation of a Destination Management Marketing Organization for the islands of the North Aegean Region Greece. The research presented in this paper has been conducted and financed in the frame of this Development Program.

\section{References}

1. Abdellatif, T., Ksouri, R., Ayoun, S., \& Storai, C. (2014). The Importance of the Image of a Destination in the Choice and Intention of Revisiting: The Case of Island of Djerba. SSRN Electronic Journal, 7(7). doi:10.2139/ssrn.2562044.

2. About the American Customer Satisfaction Index. (n.d.). Retrieved July 13, 2020, from https://www.theacsi.org/about-acsi.

3. Ahmetaj, R. (2019). Tourist satisfaction survey in Prizren. Retrieved July 14, 2020, from https://www.academia.edu/41881249/Tourist_satisfaction_survey_in_Prizren.

4. Akama, J. S., \& Kieti, D. M. (2003). Measuring tourist satisfaction with Kenya's Wildlife Safari: A case study of Tsavo West National Park. International Journal of Tourism Management, 24(1), 73-81. http://dx.doi.org/10.1016/S0261-5177(02)00044-4.

5. Aliman, N. K., Hashim, S. M., Wahid, S. D., \& Harudin, S. (2016). Tourists' Satisfaction with a Destination: An Investigation on Visitors to Langkawi Island. International Journal of Marketing Studies, 8(3), 173. doi:10.5539/ijms.v8n3p173.

6. Andrades, L., Dimanche, F., \& Likevich, S. (2015). Tourist Behaviour and Trends. Tourist Behaviour and Trends. Available at:

https://www.academia.edu/25114825/Tourist_Behaviour_and_Trends?auto=download.

7. Angelova, B., \& Zekiri, J. (2011). Measuring Customer Satisfaction with Service Quality Using American Customer Satisfaction Model (ACSI Model). International Journal of Academic Research in Business and Social Sciences, 1(3), 27. doi:10.6007/ijarbss.v1i2.35.

8. Beigpoor Shahrivar, R. (2012). Factors that influence tourist satisfaction. Journal of Travel and Tourism Research (on Line), 12. Retrieved July 14, 2020, from https://www.researchgate.net/publication/284969853_Factors_that_influence_tourist_satisfaction/citation /download.

9. Alcañiz, J. E. B., \& Simó, L. A. (2004). Cognitive-affective model of satisfaction in leisure and tourism services. Notebooks on Economics and Business Management, 21, 89-120. Available at: https://dialnet.unirioja.es/servlet/articulo?codigo=1143456.

10.Bosque, I. A., Martín, H. S., \& Collado, J. (2006). The role of expectations in the consumer satisfaction formation process: Empirical evidence in the travel agency sector. Tourism Management, 27(3), 410-419. doi:10.1016/j.tourman.2004.10.006.

11.Buhalis, D., \& Law, R. (2008). Progress in information technology and tourism management: 20 years. Tourism Management, 29(4), 609-623. https://doi.org/10.1016/j.tourman.2008.01.005.

12.Buhalis, D. (1993). RICIRMS as a strategic tool for small and medium tourism enterprises. Tourism Management, 14(5), 366-378. https://doi.org/10.1016/0261-5177(93)90005-6.

13.Buhalis, D. (1998). Strategic use of information technologies in the tourism industry. Tourism Management, 19(5), 409-421. https://doi.org/10.1016/S0261-5177(98)00038-7.

14.Bulanmir. (n.d.). TOPICS. Retrieved July 14, 2020, from https://destinet.eu/topics.

15.Capriello, A., Mason, P. R., Davis, B., \& Crotts, J. C. (2013). Farm tourism experiences in travel reviews: A cross-comparison of three alternative methods for data analysis. Journal of Business Research, 66(6), 778-785. doi:10.1016/j.jbusres.2011.09.018.

16.Cetin, G., \& Bilgihan, A. (2015). Components of cultural tourists' experiences in destinations. Current Issues in Tourism, 19(2), 137-154. doi:10.1080/13683500.2014.994595.

17.Chen, C.C., Huang, W. J., \& Petrick, J.F. (2016). Holiday recovery experiences, tourism satisfaction and life satisfaction-Is there a relationship? Tourism Management, 53, 140-147. https://doi.org/10.1016/j.tourman.2015.09.016.

18.Chen, C. F., \& Tsai, D. (2007). How destination image and evaluative factors affect behavioral intentions. Tourism Management, 28, 1115-1122. http://dx.doi.org/10.1016/j.tourman.2006.07.007.

19.Chen, C., \& Chen, F. (2010). Experience quality, perceived value, satisfaction and behavioral intentions for heritage tourists. Tourism Management, 31, 29-35. http://dx.doi.org/10.1016/j.tourman.2009.02.008. 
20.Chen, P.J., \& Kerstetter, D.I. (1999). International students' image of rural Pennsylvania as a travel destination. Journal of Travel Research, 37(3), 256-266. http://dx.doi.org/10.1177/004728759903700307.

21.Chen, X., Cheng, Z., \& Kim, G. (2020). Make It Memorable: Tourism Experience, Fun, Recommendation and Revisit Intentions of Chinese Outbound Tourists. Sustainability, 12(5), 1904. doi:10.3390/su12051904.

22.Chu, R. K., \& Choi, T. (2000). An importance-performance analysis of hotel selection factors in the Hong Kong hotel industry: a comparison of business and leisure travelers. Tourism management, 21(4), 363-377. https://doi.org/10.1016/S0261-5177(99)00070-9.

23.Chung, J.Y., \& Buhalis, D. (2008). Information needs in online social networks. Information Technology \& Tourism, 10(4), 267-281. https://doi.org/10.3727/109830508788403123.

24.Confente, I. (2015). Twenty-five years of word-of-mouth studies: A critical review of tourism research. International Journal of Tourism Research, 17, 613-624. https://doi.org/10.1002/jtr.2029.

25.Corte, V.D. (2015). Customer Satisfaction in Tourist Destination: The Case of Tourism Offer in the City of Naples. Journal of Investment and Management, 4(1), 39. doi:10.11648/j.jim.s.2015040101.16.

26.Constantoglou M., Prinitis M. (2020). Tourism Destination Crisis Management: The case study of Lesvos island, Greece. Journal on Tourism \& Sustainability 3(2), 14-31. Available at: http://www.ontourism.online/index.php/jots/article/view/80.

27.Crompton, J.L. (1979). Motivation for pleasure vacations. Annals of Tourism Research, 6, 408-424. https://doi.org/10.1016/0160-7383(79)90004-5.

28.Crotts, J.C., \& Erdmann, R. (2000). Does national culture influence consumers' evaluation of travel services? A test of Hofstede's model of cross-cultural differences. Managing Service Quality: An International Journal, 10(6), 410-419. https://doi.org/10.1108/09604520010351167.

29.Dann, G. (1977). Anomie, Ego-Enhancement and Tourism. Annals of Tourism Research, 4(2), 184-194. https://doi.org/10.1016/0160-7383(77)90037-8.

30.Dixit, S. K. (2017). The Routledge handbook of consumer behaviour in hospitality and tourism. London: Routledge, Taylor \& Francis Group. Available at: https://doi.org/10.4324/9781315659657.

31.Dredge, D. (2016). Are DMOs on a path to redundancy? Tourism Recreation Research, 41(3), 348-353. https://doi.org/10.1080/02508281.2016.1195959.

32.Eusebio \& Vieria (2013). Destination Attributes' Evaluation, Satisfaction and Behavioural Intentions: A Structural Modelling Approach. International Journal of Tourism Research, 15(1), 66-80. DOI:https://doi.org/10.1002/jtr.877.

33.Fathimath, A. (2017). Impact of municipal amalgamation on stakeholder collaboration: The case of Auckland, New Zealand. Kötuitui: New Zealand Journal of Social Sciences Online, 12(2), 221-234. doi:10.1080/1177083x.2017.1367313.

34.Figueroa, A. (n.d.). Definition of DMO in Travel and Tourism. Retrieved July 14, 2020, from https://www.tripsavvy.com/what-is-a-dmo-3252439.

35.Franzoni, S. (2015). Measuring the sustainability performance of the tourism sector. Tourism Management Perspectives, 16, 22-27. doi:10.1016/j.tmp.2015.05.007.

36.Franzoni, S., \& Bonera, M. (2019, January 18). How DMO Can Measure the Experiences of a Large Territory. Retrieved July 13, 2020, from https://www.mdpi.com/2071-1050/11/2/492/htm.

37.Füller, J., \& Matzler, K. (2008). Customer delight and market segmentation: An application of the threefactor theory of customer satisfaction on lifestyle groups. Tourism management, 29(1), 116-126. https://doi.org/10.1016/j.tourman.2007.03.021.

38.Gaki, E., Kostopoulou, S., Parisi, E., \& Lagos, D. (2016). The evaluation of tourism satisfaction in island destinations: The case of the Ionian Islands of Greece. Retrieved July 14, 2020, from https://www.econstor.eu/bitstream/10419/174645/1/Paper0295 EleniGaki.pdf.

39.Galvani, A., Lew, A. A., \& Perez, M. S. (2020). COVID-19 is expanding global consciousness and the sustainability of travel and tourism. Tourism Geographies, 22(3), 567-576. https://doi.org/10.1080/14616688.2020.1760924.

40.Giese, J.L., \& Cote, J.A. (2000). Defining Consumer Satisfaction. Academy of Marketing Science Review. No 1. http://www.amsreview.org/articles/giese01-2000.pdf.

41.González, M. E., Comesaña, L.R., \& Brea, J.A. (2007). Assessing tourist behavioral intentions through perceived service quality and customer satisfaction. Journal of Business Research, 60(2), 153-160. doi:10.1016/j.jbusres.2006.10.014.

42.Gössling, S., Scott, D., \& Hall, C.M. (2020). Pandemics, tourism and global change: A rapid assessment of COVID-19. Journal of Sustainable Tourism, 1-20. doi:10.1080/09669582.2020.1758708. 
43.Gounaris, S., Dimitriadis, S., \& Stathakopoulos, V. (2010). An examination of the effects of service quality and satisfaction on customers' behavioral intentions in e-shopping. Journal of Services Marketing, 24(2), 142-156. doi:10.1108/08876041011031118.

44.Gountas, J., \& Gountas, M. (2007). Personality orientations, emotional states, customer satisfaction, and intention to repurchase. Journal of Business Research, 60, 72-75. https://doi.org/10.1016/j.jbusres.2006.08.007.

45.Gretzel, U., Fesenmaier, D.R., Formica, S., \& O'Leary, J.T. (2006). Searching for the Future: Challenges Faced by Destination Marketing Organizations. Journal of Travel Research, 45(2), 116-126. doi:10.1177/0047287506291598.

46.Grönroos, C. (1994). From marketing mix to relationship marketing: Towards a paradigm shift in marketing. Management Decision, 32(2), 4-20. https://doi.org/10.1016/S1320-1646(94)70275-6.

47.Hall, C.M., \& Veer, E. (2016). The DMO is dead. Long live the DMO (or, why DMO managers do not care about post-structuralism). Tourism Recreation Research, 41(3), 354-357. doi:10.1080/02508281.2016.1195960.

48.Hall, C.M. (2010). Researching the political in tourism: Where knowledge meets power, 7-19. In: Hall, C.M. (Ed.). (2010). Fieldwork in Tourism. London: Routledge, https://doi.org/10.4324/9780203845516.

49.Hall, C.M. (2011b). Yes, Virginia, there is a tourism class. Why class still matters in tourism analysis, 111-125, IN: Mosedale, J. (Ed.). (2011). Political Economy of Tourism. London: Routledge, https://doi.org/10.4324/9780203835876.

50.Hall, C.M. (2014). Review of "Competitiveness and tourism". Journal of Sustainable Tourism, 22(5), 842-846. https://doi.org/10.1080/09669582.2013.820886.

51.Haung, F., \& Su, L. (2010). A Study on the relationships of service fairness, quality, value, satisfaction, and loyalty among rural tourists. Paper presented at the 7th International Conference on Service Systems and Service Management, Tokyo. http://dx.doi.org/10.1109/icsssm.2010.5530137.

52.Hays, S., Page, S.J., \& Buhalis, D. (2013). Social media as a destination marketing tool: Its use by national tourism organisations. Current Issues in Tourism, 16(3), 211-239. doi:10.1080/13683500.2012.662215.

53.Hellenic Statistical Authority (2018). Estimated Population (1.1.2019) and Migration Flows of the Country (2018). Retrieved July 14, 2020, from https://www.statistics.gr/documents/20181/79d452ad-8f9e-c6eb9f0e-82916e714866.

54.Herle, F. (2018). The Impact of Destination Image on Tourists' Satisfaction and Loyalty in the Context of Domestic Tourism. Marketing - from Information to Decision Journal, 1(2), 14-26. doi:10.2478/midj2018-0007.

55.Higgins-Desbiolles, F. (2020). Socialising tourism for social and ecological justice after COVID-19. Tourism Geographies, 1-14. https://doi.org/10.1080/14616688.2020.1757748.

56.Hunt, J.D. (1975). Image as a factor in tourist development. Journal of Travel Research, 13(3), 1-7. http://dx.doi.org/10.1177/004728757501300301.

57.Insete Intelligence (2020). Retrieved July 2020. https://www.google.com/url?sa=t\&rct=j\&q=\&esrc=s\&source=web\&cd=\&cad=rja\&uact=8\&ved=2ahUK EwiL3OPK8brrAhUGDxQKHfSPAP0QFjAAegQIBRAB\&url=https\%3A\%2F\%2Finsete.gr\%2Fwpcontent\%2Fuploads\%2F2020\%2F07\%2FNorth_Aegean_Region.xlsx\&usg=AOvVaw1AAFocAIqOPaRd WtgbunJs.

58.Ioannides, D., \& Gyimóthy, S. (2020). The COVID-19 crisis as an opportunity for escaping the unsustainable global tourism path. Tourism Geographies, 1-9. https://doi.org/10.1080/14616688.2020.1763445.

59.Jang, S. and Feng, R. (2007). Temporal destination revisit intention: the effects of novelty seeking and satisfaction. Tourism Management, 28, 580-90. DOI:10.1016/j.tourman.2006.04.024.

60.Kassean, H., \& Gassita, R. (2013). Exploring tourists push and pull motivations to visit Mauritius as a tourist destination. African Journal of Hospitality, Tourism and Leisure, 2(3), 1-13. Available at: http://www.ajhtl.com/uploads/7/1/6/3/7163688/article_5_2013.pdf.

61.Kim, C. (1999). Cross- Cultural Perspectives on Motivation. Annals of Tourism Research, 26(1), 201-204. https://doi.org/10.1016/S0160-7383(98)00066-8.

62.Kim, J., Ritchie, J.R., \& Mccormick, B. (2012). Development of a Scale to Measure Memorable Tourism Experiences. Journal of Travel Research, 51(1), 12-25. doi:10.1177/0047287510385467.

63.Kozak, M. (2002). Comparative analysis of tourist motivations by nationality and destinations. Tourism Management, 23(3), 221-232. https://doi.org/10.1016/S0261-5177(01)00090-5.

64.Lai, K., \& Li, X. (2016). Tourism Destination Image. Journal of Travel Research, 55(8), 1065-1080. doi:10.1177/0047287515619693. 
65.Laing, J., Wheeler, F., Reeves, K., \& Frost, W. (2014). Assessing the experiential value of heritage assets: A case study of a Chinese heritage precinct, Bendigo, Australia. Tourism Management, 40, 180-192. doi:10.1016/j.tourman.2013.06.004.

66.Latour, S.A., \& Peat, N.C. (1979). Conceptual and methodological issues in consumer satisfaction research. In: William, L.W., (Eds.), Advances in Consumer Research, 431-437. Ann Arbor, MI: Association for Consumer Research. Available at: https://www.acrwebsite.org/volumes/9591/volumes/v06/NA-06.

67.Law, R., Buhalis, D., \& Cobanoglu, C. (2014). Progress on information and communication technologies in hospitality and tourism. International Journal of Contemporary Hospitality Management, 26(5), 727-750. https://doi.org/10.1108/IJCHM-08-2013-0367.

68.Law, R., Qi, S., \& Buhalis, D. (2010). Progress in tourism management: A review of website evaluation in tourism research. Tourism Management, 31, 297-313. https://doi.org/10.1016/j.tourman.2009.11.007.

69.Laws, E. (1991). Tourism Marketing: Service and Quality Management Perspectives. Thornes Publishers L.t.d., Old Station Drive: Leckhampton, England. https://doi.org/10.1177/0047287592031002122.

70.Lee, S., Jeon, S., \& Kim, D. (2011). The impact of tour quality and tourist satisfaction on tourist loyalty: The case of Chinese tourists in Korea. Tourism Management, 32(5), 1115-1124. http://dx.doi.org/10.1016/j.tourman.2010.09.016.

71.Lovelock, C.H. (2000). Service Marketing. NJ: Prentice Hall. Available at: https://www.academia.edu/8972616/Service Marketing by Lovelock.

72.Ma, J., Gao, J., Scott, N., \& Ding, P. (2013). Customer delight from theme park experiences: The antecedents of delight based on cognitive appraisal theory. Annals of Tourism Research, 42, 359-381. https://doi.org/10.1016/j.annals.2013.02.018.

73.Marinao, E. (2018). Determinants of Satisfaction with the Tourist Destination. Mobilities, Tourism and Travel Behavior - Contexts and Boundaries. doi:10.5772/intechopen.70343.

74.Mcdowall, S. (2010). International Tourist Satisfaction and Destination Loyalty: Bangkok, Thailand. Asia Pacific Journal of Tourism Research, 15(1), 21-42. doi:10.1080/10941660903510040.

75.McGehee, N. G., Loker-Murphy, L., \& Uysal, M. (1996). The Australian international pleasure travel market: Motivations from a gendered perspective. The Journal of Tourism Studies, 7(1), 45-57. Available at: https://www.cabdirect.org/cabdirect/abstract/19961809306.

76.Molinillo, S., Liébana-Cabanillas, F., Anaya-Sánchez, R., \& Buhalis, D. (2017, October 06). DMO online platforms: Image and intention to visit. Retrieved July 13, 2020, from https://www.sciencedirect.com/science/article/abs/pii/S026151771730211X?via=ihub.

77.Molinillo, S., Liébana-Cabanillas, F., Anaya-Sánchez, R., \& Buhalis, D. (2018). DMO online platforms: Image and intention to visit. Tourism Management, 65, 116-130. doi:10.1016/j.tourman.2017.09.021.

78.Mostafavi Shirazi, S. (2016). Assessing Tourist Satisfaction Forms The Basis For Destination Improvement. 4th Interdisciplinary Tourism Research Conference, 24-29 May 2016, Bodrum, TURKEY Available at: https://www.researchgate.net/publication/305710243_ASSESSING_TOURIST_SATISFACTION_FOR MS THE BASIS FOR DESTINATION IMPROVEMENT.

79.Möhlmann, M. (2015). Collaborative consumption: Determinants of satisfaction and the likelihood of using a sharing economy option again. Journal of Consumer Behaviour, 14(3), 193-207. https://doi.org/10.1002/cb.1512.

80.Neuhofer, B., Buhalis, D., \& Ladkin, A. (2012). Conceptualizing technology enhanced destination experiences. Journal of Destination Marketing \& Management, 1(1-2), 36-46. doi:10.1016/j.jdmm.2012.08.001.

81.Neuhofer, B., Buhalis, D., \& Ladkin, A. (2015). Smart technologies for personalized experiences: A case study in the hospitality domain. Electronic Markets, 25(3), 243-254. doi:10.1007/s12525-015-0182-1.

82.Nicolau, J.L., \& Más, F.J. (2006). The influence of distance and prices on the choice of tourist destinations: The moderating role of motivations. Tourism Management, 27(5), 982-996. doi:10.1016/j.tourman.2005.09.009.

83.Oliver, R.L. (1997). Satisfaction: A behavioural perspective on the consumer. New York: McGraw Hill. https://doi.org/10.4324/9781315700892.

84. Oliver, R.L. (2015). Satisfaction: A behavioral perspective on the consumer (2nd ed.). London: Routledge. https://doi.org/10.4324/9781315700892.

85.Oliver, R.L., \& Desarbo, W.S (1988). Response determinants in satisfaction judgment. Journal of Consumer Research, 14, 495-507. https://doi.org/10.1086/209131.

86.Oliver, R.L., \& Swan J.E. (1989). Equity and disconfirmation perceptions as influences on merchant and product satisfaction. Journal of Consumer Research, 16, 372-383. https://doi.org/10.1086/209223. 
87.Oliver, R.L., \& Swan, J.E. (1989). Consumer perceptions on interpersonal equity and satisfaction in transactions: A field survey approach. Journal of Marketing, 53(2), 21-35. http://dx.doi.org/10.2307/1251411.

88. Oliver, R.L. (1980). A cognitive model of the antecedence and consequences of satisfaction decisions. Journal of Marketing Research, 17, 46-59. https://doi.org/10.1177/002224378001700405.

89.Page, S.J. (2011). Tourism management: An introduction (4th ed.). London: Routledge. https://doi.org/10.4324/9781315768267.

90.Page, S., \& Connell, J. (2006). Tourism a modern synthesis. London: Thomson Learning. DOI:10.1016/j.tourman.2006.11.007.

91.Pike, S., \& Page, S. (2014). Destination marketing organizations and destination marketing: A narrative analysis of the literature. Tourism Management, 41, 202-227. DOI:10.1016/j.tourman.2013.09.009.

92.Pizam, A., Neumann, Y. and Reichel, A. (1978). Dimensions of tourist satisfaction area. Annals of tourism research, 5, 314-322. https://doi.org/10.1016/0160-7383(78)90115-9.

93.Poon, A. (1993). Tourism, technology and competitive strategies. Oxford: CAB International. https://doi.org/10.1177/004728759403200372.

94.Reisinger, Y., \& Turner, L. (1997). Cross-cultural differences in tourism: Indonesian tourists in Australia. Tourism Management, 18(3), 139-147. https://doi.org/10.1016/S0261-5177(96)00115-X.

95.Reisinger, Y., \& Turner, L. (1998). Cross-cultural differences in tourism: A strategy for tourism marketers. Journal of Travel \& Tourism Marketing, 7(4), 79-106. https://doi.org/10.1300/J073v07n04 05.

96.Rodriguez Del Bosque, I. A., San Martin, H., \& Collado, J. (2006). The role of expectations in the consumer satisfaction formation process: Empirical evidence in the travel agency sector. Tourism Management, 27, 410-419. DOI:10.1016/j.tourman.2004.10.006.

97.Ross, G. F. (1993). Destination evaluation and vacation preferences. Annals of Tourism Research, 2(3),477-489. http://dx.doi.org/10.1016/0160-7383(93)90004-M.

98.Sadeh, E., Asgari, F., Mousavi, L., \& Sadeh, S. (2012). Factors affecting tourist satisfaction and its consequences. Journal of Basic and Applied Scientific Research, 2(2), 1557-2012. Available at: semanticscholar.org/paper/Factors-Affecting-Tourist-Satisfaction-and-Its-SadehAsgari/baeaa774de4575876d2c028f37511cd60d566a2c

99. Sharma, G., \& Baoku, L. (2013). Customer satisfaction in Web 2.0 and information technology development. Information Technology and People, 26(4), 347-367. DOI:10.1108/ITP-12-2012-0157.

100. Sheldon, P.J. (1997). Tourism information technology. Oxford: CAB International. Available at: https://books.google.com.ua/books/about/Tourism Information Technology.html?id=vEMaAQAAMA AJ\&redir_esc $=y$.

101. Shim, C., \& Santos, C.A. (2014). Tourism, place and placelessness in the phenomenological experience of shopping malls in Seoul. Tourism Management, 45, 106-114. doi:10.1016/j.tourman.2014.03.001.

102. Song, H., van der Veen, R., Li, G., \& Chen, J. L. (2012). The Hong Kong tourist satisfaction index. Annals of Tourism Research, 39(1), 459-479. https://doi.org/10.1016/j.annals.2011.06.001.

103. Sparks, B. A., \& Browning, V. (2010). Complaining in cyberspace: The motives and forms of hotel guests' complaints online. Journal of Hospitality Marketing \& Management, 19(7), 797-818. https://doi.org/10.1080/19368623.2010.508010.

104. Stylos, N., Bellou, V., Andronikidis, A., \& Vassiliadis, C. A. (2017). Linking the dots among destination images, place attachment, and revisit intentions: A study among British and Russian tourists. Tourism Management, 60, 15-29. doi:10.1016/j.tourman.2016.11.006.

105. Survicate., H. (2020, April 03). Customer Satisfaction: 5 Reasons Why is Important in 2020. Retrieved July 13, 2020, from https://survicate.com/customer-satisfaction/importance-customer-satisfaction/.

106. Thusyanthy, V., \& Tharanikaran, V. (2017). Antecedents and Outcomes of Customer Satisfaction: A Comprehensive Review. International Journal of Business and Management, 12(4), 144. doi:10.5539/ijbm.v12n4p144.

107. Tung, V.W., \& Ritchie, J.B. (2011). Exploring the essence of memorable tourism experiences. Annals of Tourism Research, 38(4), 1367-1386. doi:10.1016/j.annals.2011.03.009.

108. Tuohino, A.H. and Konu, H. (2014). Local stakeholders' views about destination management: who are leading tourism development? Tourism Review, 69(3), 202-215. DOI:10.1108/TR-08-2014-0050.

109. Tovmasyan, G. (2019). Assessment of Tourist Satisfaction Index: Evidence from Armenia. Marketing and Management of Innovations, 3, 22-32. Available at: https://mmi.fem.sumdu.edu.ua/sites/default/files/02_A282.pdf. 
110. Turner, L.W., Reisinger, Y.V., \& McQuilken, L. (2002). How cultural differences cause dimensions of tourism satisfaction. Journal of Travel \& Tourism Marketing, 11(1), 79-101. https://doi.org/10.1300/J073v11n01 05.

111. Uncles, M.D., East, R., \& Lomax, W. (2013). Good customers: The value of customers by mode of acquisition. Australasian Marketing Journal (AMJ), 21(2), 119-125. doi:10.1016/j.ausmj.2013.02.003.

112. Uysal, M., \& Jurowski, C. (1994). Testing the push and pull factors. Annals of Travel Research, 21(4), 844-846. DOI:10.1016/0160-7383(94)90091-4.

113. Vuuren, C.V., \& Slabbert, E. (2011). Travel motivations and behaviour of tourists to a south African resort. Travel motivations and behaviour of tourists to a south African resort, 1. DOI:10.1016/01607383(94)90091-4.

114. Wan, L.C., \& Chu, M.Y. (2013). Cross-Cultural Research on Consumer Responses to Service Failure: A Critical Review. Multinationals and Global Consumers, 185-206. doi:10.1057/9781137307293_9.

115. Wang, Y. (2016). More important than ever: measuring tourist satisfaction. Griffith Institute for Tourism Research Report No 10. https://www.griffith.edu.au/_data/assets/pdf_file/0029/18884/MeasuringTourist-Satisfaction.pdf.

116. Wesley, S., Lehew, M., \& Woodside, A.G. (2006). Consumer decision-making styles and mall shopping behavior: Building theory using exploratory data analysis and the comparative method. Journal of Business Research, 59, 535-548. DOI:10.1016/j.jbusres.2006.01.005.

117. White, C.J. (2006). Towards an Understanding of the Relationship between Mood, Emotions, Service Quality and Customer Loyalty Intentions. The Service Industries Journal, 26(8), 837-847. doi:10.1080/02642060601011624.

118. Woodside, A.G., \& Dubelaar, C. (2002). A general theory of tourism consumption systems: A conceptual framework and an empirical exploration. Journal of Travel Research, 41, 120-132. DOI: $10.1177 / 004728702237412$.

119. Woodside, A.G., Ramos-Mir, V., \& Duque, M. (2011). Tourism's destination dominance and marketing website usefulness. International Journal of Contemporary Hospitality Management, 23(4), 552-564. DOI:https://doi.org/10.1108/09596111111130038.

120. WTO (2007). A Practical Guide to Tourism Destination Management, Madrid. Available at: https://www.unwto.org/global/publication/practical-guide-tourism-destination-management.

121. WTO (2020). Stay healthy, travel responsibly. Available at://www.unwto.org/health-advice-for-tourists.

122. WTTC (2020). Traveller COVID-19 hub. Available at: https://wttc.org/engb/COVID-19/Traveller-Hub.

123. Wu, H., \& Chang, Y. (2020). Relationships between secure attachment, experiential co-creation and future experiential intentions in the tourism industry: The case of COVID-19. 1-43. doi:10.21203/rs.3.rs$34557 / \mathrm{v} 1$.

124. Yoon, Y., Uysal, M. (2005). An examination of the effects of motivation and satisfaction on the destination loyalty: a structural model. Tourism Management, 26, 45-56. DOI:10.1016/j.tourman.2003.08.016.

125. Yu, L., \& Goulden, M. (2006). A comparative analysis of international tourists' satisfaction in Mongolia. Tourism Management, 27(6), 1331-1342. https://doi.org/10.1016/j.tourman.2005.06.003. 